Working Paper/Document de travail 2012-18

\title{
Consumer Bankruptcy and Information
}

by Jason Allen, H. Evren Damar and David Martinez-Miera 
Bank of Canada Working Paper 2012-18

July 2012

\title{
Consumer Bankruptcy and Information
}

\author{
by
}

\author{
Jason Allen, ${ }^{1}$ H. Evren Damar ${ }^{1}$ and David Martinez-Miera ${ }^{2}$ \\ 1Financial Stability Department \\ Bank of Canada \\ Ottawa, Ontario, Canada K1A OG9 \\ 2Universidad Carlos III de Madrid
}

Bank of Canada working papers are theoretical or empirical works-in-progress on subjects in economics and finance. The views expressed in this paper are those of the authors. No responsibility for them should be attributed to the Bank of Canada. 


\section{Acknowledgements}

We thank the Office of the Superintendent of Bankruptcy for their support. We thank Sheisha Kulkarni, Jim MacGee, Randall Morck, Adi Mordel, Teodora Paligorova, Barry Scholnick, Reint Gropp, Mark Zelmer and seminar participants at the Bank of Canada, European Central Bank, the Office of the Superintendent of Bankruptcy's Symposium on Insolvency and Financial Literacy Research, University of Alberta, University of Victoria, Lakehead University and the Competition Bureau. Part of this research was done when David Martinez-Miera was a visiting scholar at the Bank of Canada. Andrew Usher, Chloé Yao and Mark Rempel provided excellent research assistance. All errors are our own. 


\begin{abstract}
We analyze the relationship between the intensity of banks' use of soft-information and household bankruptcy patterns. Using a unique data set on the universe of Canadian household bankruptcies, we document that bankruptcy rates are higher in markets where the collection of soft, or qualitative locally gathered information, is the weakest. Using two Canadian bank mergers as exogenous variation in local market structure, we show that the differences in bankruptcy rates are not due to changes in the supply of credit. Our findings indicate that screening via hard-information is not a perfect substitute for softinformation. Instead, the two appear to be complements.
\end{abstract}

JEL classification: G2, D4

Bank classification: Financial institutions; Financial services

\title{
Résumé
}

Les auteurs analysent la relation qu'il y a entre l'intensité avec laquelle les banques exploitent des données subjectives ou "informelles » et les tendances entourant les faillites de ménages. À partir d'un ensemble unique de données sur les faillites de ménages canadiens, ils confirment que les taux de faillite sont plus élevés dans les marchés où il se recueille le moins d'informations subjectives, c.-à-d. de renseignements qualitatifs obtenus par les succursales. En traitant deux fusions de banques canadiennes comme des facteurs de variation exogènes de la structure d'un marché local, les auteurs montrent que les différences entre les taux de faillite ne sont pas causées par des modifications de l'offre de crédit. Leurs résultats indiquent que les données objectives utilisées pour la sélection des emprunteurs ne constituent pas de substituts parfaits des données subjectives: en réalité, les deux types d'informations s'avèrent complémentaires.

Classification JEL : G2, D4

Classification de la Banque : Institutions financières; Services financiers 


\section{Introduction}

Household debt levels around the world are at, or near record highs. The widespread adoption of information-enhancing technologies (e.g. credit scoring) have helped financial institutions price consumer risk (Edelberg 2006) and increased their ability to lend. Livshits et al. (2011) suggest these technologies enabled banks to lend to households that were previously excluded from credit markets, causing the substantial increase in bankruptcies documented, among other places, in the United States by Dick and Lehnert (2010). Papers focused on the financial crisis, on the other hand, have tended to emphasize the reduction in lending standards due to securitization (Keys et al. (2010)). Post-crisis, as financial institutions refocus their screening and monitoring efforts, using hard information, we argue that the complimentary channel of soft information should not be ignored by lenders assessing the credit quality of a borrower.

The focus of this paper is on the intensity of the lender-borrower relationship, and its potential impact on consumer bankruptcy patterns. Since borrowers have private information, banks engage in information acquisition to reduce the presence of this informational asymmetry on the ability to repay the loan. For this purpose, banks can gather hard and soft information about the borrower to deduce the likelihood of repayment. Hard information involves the "mechanical" analysis of qualitative information by banks. The best-known example is credit scoring, which uses easily transferable information to determine the credit worthiness of a borrower. Soft information, on the other hand, is usually gathered and processed by humans and not easily transferable. This type of information gathering is mostly done through branches, which are in the best position to keep up-to-date on local economic conditions or form relationships with individual customers. We refer to the intensity of soft information gathering and processing by a financial institution as its "soft information capture."

That recent advances in hard information technology are associated with higher default rates has been fairly well established in the banking literature. Recent studies by Dick and Lehnert (2010) and Livshits et al. (2011) assert that the link between credit scoring and higher bankruptcy is the "extensive margin" - the adoption of credit scoring allow lenders to extend credit to previously excluded risky borrowers. The bankruptcy/default rate rises along with the number of borrowers in the economy. Dick and Lehnert (2010) base their conclusion on the observation that while bankruptcy rates rose in the U.S. following the widespread adoption of credit scoring by smaller

banks, overall bank risk decreased. They assert that this would not be possible if credit scoring increased the probability of default by existing borrowers (i.e. the "intensive margin").

While credit scoring technologies undoubtedly improve bank lending decisions, soft information gathered locally through branches can also play a role in reducing bankruptcies. We treat a bank branch as (among other things) a fixed investment in soft information capacity. The amount of loans issued and serviced by a local branch, therefore, determines how much soft information the bank uses in a market. If a branch services many customers/loans, then it will not be able to form 
relationships and capture sufficient soft information on each customer. In these cases, and given adjustment costs in branching decisions, the bank will have to rely mostly (or exclusively) on hard information while making lending decisions.

Unlike credit scoring technologies, which are centrally adopted and used wherever the bank makes loans, the branch presence of a bank varies across local markets. We use this variation to argue that in areas where banks have a light branch presence, with respect to their loan volumes, the bankruptcy rate will be higher. Furthermore, we argue that this variation is at least partially due to the intensive margin, where the absence of soft information capture leads to higher default rates for existing borrowers. We take two approaches. First, we take a direct approach, regressing market bankruptcy rates on market soft information capacity rates. This approach, although favored for its simplicity, may suffer from endogeniety. That is, lenders may close branches or reduce lending in high bankruptcy areas. For robustness, therefore, we use an indirect approach which relies on analyzing the impact of mergers on bankruptcy rates. We argue that mergers lead to exogenous changes in local market structure, which allows us to identify the impact of these changes on bankruptcy rates. This approach is indirect because market structure indirectly captures soft information capacity. A merger affects the merging parties' governance structure and therefore total reliance on hard versus soft information when making lending decisions (Stein (2002)) as well as lending decisions of rivals (Sapienza (2002)). These may have an effect on soft information capture of one or both types of lenders. For example, if rivals try to increase their market share post-merger, they may not be able to monitor their portfolio of loans as effectively as pre-merger.

Canada provides an almost ideal case for analyzing the link between soft information and consumer bankruptcies. Canada's mortgage market does not feature an "originate-to-distribute" model, and so it's doubtful that lending standards were influenced by factors such as securitization. Second, the majority of Canadian lenders were already using information-enhancing technologies by the mid-1990s, so it is unlikely that bankruptcy rates after this time were influenced by local lenders adopting such technologies. Third, unlike the U.S., where the number of bank branches were actually increasing at the same time banks adopted credit-scoring technologies, in Canada there was a widespread decrease in the number of bank branches, some of it the result of acquisitions of community banks by national banks, implying a clear decrease in banks' soft information collection abilities. This raises the possibility that in Canada banks were substituting hard information for soft information in some markets, and this tactic reflected itself as higher bankruptcy rates in the affected markets. Using Canadian data therefore allows us to identify the effect of branch presence on bankruptcy. The increased branch presence in the U.S. while credit scoring was being widely adopted leads to more difficult identification of the full impact of soft information on bankruptcy.

Our empirical findings suggest that bankruptcies were higher in certain local markets, not because banks relaxed lending standards, but because they substituted out of soft information. We find, for example, that a one standard deviation decrease in soft information is associated with up 
to a $10 \%$ increase in bankruptcy rates. In comparison to many existing studies in the literature that have looked at either hard or soft information in bank lending, ours is one of the few papers that attempts to capture the tradeoff between the two. We also argue that this soft information channel needs to be properly accounted for, in order to fully understand the links between information, credit scoring technologies, the supply of consumer credit and consumer bankruptcies.

A number of papers have argued that hard information does not necessarily dominate soft information in lending decisions. Using a panel of Finnish cooperative banks, Hyytinen and Toivanen (2004) find that investments in branch network density and human capital improve a bank's monitoring ability and decrease credit losses. However, it is unclear if the credit losses are due to a decrease in lending or better monitoring capabilities. Loutskina and Strahan (2011) establish a link between more soft information capture, increased lending and lower credit losses. They find that local banks who issue more information-sensitive mortgages and depend on private information have lower credit losses despite higher acceptance rates and riskier applicants than national banks who are more likely to issue conformable mortgages that are easily securitizable and therefore do not require monitoring. Since the definition of "private" information in Loutskina and Strahan (2011) is quite similar to soft information, both their findings and the findings in Hyytinen and Toivanen (2004) support our findings that there exists a high degree of compatibility between hard and soft information. Finally, Agarwal et al. (2012) find that lenders can reduce credit losses in the home equity credit market by using soft information during negotiations with borrowers on top of the reduction in credit losses achieved by using hard information scoring to initiate a "first offer."

The paper is structured as follows. Section 1 presents a general discussion of consumer bankruptcy in Canada. We discuss our data sources in Section 2 and show some general characteristics of Canadian bankruptcy filers and the household sector. Section 3 presents the key testable hypotheses, motivated by a model of branching and bankruptcies, while Section 4 presents the empirical results. Section 5 exploits exogenous changes in market structure due to merger activity to expand our analysis. Robustness checks are discussed in Section 6. Section 7 concludes.

\section{Consumer Bankruptcies in Canada}

\subsection{The Bankruptcy Process in Canada}

In Canada, consumer insolvencies are governed by the Bankruptcy and Insolvency Act (BIA) and supervised by the Office of the Superintendent of Bankruptcy (OSB). Consumers facing insolvency can either file for bankruptcy or file a debt-restructuring proposal. A proposal does not require the assets of the consumer to be liquidated; rather if the proposal is accepted by the creditors, the consumer makes payments on outstanding unsecured debts for a pre-specified period of time. This 
procedure is similar to a Chapter 11 filing in the U.S. ${ }^{1}$

If the consumer decides to pursue the bankruptcy option, he/she is required to work with a bankruptcy trustee, who charges a fee for their services. Once the consumer is declared to be bankrupt by the OSB, the trustee directly negotiates with the consumer's creditors. The trustee is also responsible selling the individual's assets and determining their stream of payments during bankruptcy (based on OSB guidelines and other factors such as the filer's family situation, etc.). First-time filers who fulfill all bankruptcy requirements are automatically discharged after nine months and make a "fresh start." ${ }^{2}$ All other filers obtain a recommendation from their trustee and attend a discharge hearing before leaving bankruptcy. During this hearing, they may be given full discharge, or a "conditional discharge" meaning that although they are out of bankruptcy they have to continue making payments. Overall, this procedure is equivalent to a Chapter 7 bankruptcy filing in the U.S. However, unlike the U.S., consumers in Canada do not have to wait for a fixed period of time before being able to file another proposal or file for bankruptcy again.

\subsection{Trends in Canadian Insolvencies}

Figure 1 shows the increase in bankruptcies per 1,000 adults between 1987 and 2008. For our sample period the national bankruptcy rate in Canada was relatively stable. The spike in bankruptcies between 1987 and 1996 could be due to an expansion of consumer credit at the extensive margin (as in Livshits et al. (2011)), as banks and credit unions in Canada adopted credit scoring methods. Putting these figures in context, Serra (2008) reports that in 2004, the U.S. had 7.0 insolvencies (Chapter 7 and Chapter 13) per thousand, while the United Kingdom and Austria had 1.1 and 1.6 insolvencies per thousand respectively. This suggests that consumer bankruptcy rates in Canada are between those of the U.S. and Europe. Finally, although proposals increase sharply between 1998 and 2007 they account for a relatively low fraction of consumer insolvencies.

\section{[INSERT FIGURE 1 HERE]}

The stability of the national bankruptcy rate is likely because our sample period is not contaminated by the recent financial crisis. Additionally, the defaults of lower quality loans made by banks using the "originate-to-distribute" model of lending do not play a role in our sample. Such issues related to the "originate-to-distribute" model and lending standards do not fully apply in Canada, since securitization of consumer loans (mortgages or otherwise) is not as common in Canada as it is in the United States. For example, Freedman and Engert (2003) report that in 2003, only $11 \%$

\footnotetext{
${ }^{1}$ There are some important differences across countries regarding judge's discretion and the time frame and scope for repeated submissions, which tend to favor creditors in Canada.

${ }^{2}$ Even after a "fresh start" some of the filer's debts, such as child support or court ordered payments are not discharged. Student loan debts are discharged only if the filer has been out of school for a lengthy period of time (10 years during our sample period, decreased to 7 years in 2009).
} 
of Canadian residential mortgages were securitized, compared to almost $50 \%$ in the U.S. Similarly, the share of all consumer credit that was securitized was only $20 \%$ in Canada.

Looking at bankruptcy filings at the local market level, however, reveals substantial heterogeneity not apparent in the national bankruptcy statistics. While the growth rate of the aggregate bankruptcy rate was close to $-0.7 \%$ during our sample period, there is substantial variation at the local level. Figure 2 provides a histogram of the annualized growth rate of bankruptcies between 1998 and 2007 at the "forward sortation area" (FSA) level (our local market definition will be described in full detail in section 4.1). While some local markets have growth rates close to zero, there are other markets where the bankruptcy rate either fell or rose by a substantial amount (for example, $\pm 4 \%$ a year). Our primary goal is to better understand the relationship between the heterogeneity in bankruptcy rates across different local markets and lenders' assessments of borrower creditworthiness.

[INSERT FIGURE 2 HERE]

\section{Data}

\subsection{Individual-Level Bankruptcy Data}

Our sample contains all bankruptcy filings in Canada for the years 1998-2007. We observe each filers location, total assets and total liabilities. We have additional information on households who filed for bankruptcy electronically. In 2003, around $20 \%$ of filings were completed electronically compared to $98 \%$ by 2007 . For these e-filers, we have information on gender, age, marital status, household size, occupation of the primary filer, income (11 categories), value of assets ( 15 categories) and value of liabilities (10 categories). This information allows us to better understand the characteristics of bankruptcy filers and to determine some of the credit-demand factors that contribute to their bankruptcy decisions.

The data on electronic bankruptcy filings for 2003-2007 suggests that the majority of households declaring bankruptcy are renters. Consistent with what Domowitz and Sartain (1999) find for the U.S., about 20 per cent of filers own a home, about the same percentage as those who own a mortgage. Table 1 presents the aggregate number of bankruptcy filers, e-filers, homeowners and mortgage holders.

\section{[INSERT TABLE 1 HERE]}

Panel A of Table 2 provides information on the main categories of creditors; banks (including mortgages, personal loans, bank-issued credit cards), non-bank issued credit cards (which includes retail chains such as Wal-Mart, Circuit City, etc.), government, and other finance companies (including companies such as Wells Fargo, Investor Group, payday lenders, and auto finance companies). 
Panel B of Table 2 presents the frequency by the number of debt contracts owed in each category. Banks are the major creditors, followed by non-bank credit card issuers while government, even after accounting for student loans, is a relatively small creditor.

\section{[INSERT TABLE 2 HERE]}

Ignoring strategic motives, a household's bankruptcy decision is largely motivated by negative shocks to their financial situation. Loss of income due to unemployment, medical expenses and divorce are documented to be the most common of such shocks both in the U.S. (Domowitz and Sartain (1999), Dick and Lehnert (2010)) and in Canada (Marketing (2002)). These factors are reflected in the occupations of all persons who filed for bankruptcy between 1998 and 2007, presented in Table 3. Almost $25 \%$ of filers are either unemployed or retired, while "sales and services" is the largest occupation category.

[INSERT TABLE[3 HERE]

\subsection{Data on All Canadian Households}

We supplement the data on bankrupt individuals with the Canadian Financial Monitor (CFM) survey to look at patterns in the overall population. This is an Ipsos-Reid administered repeated cross-sectional survey which asks approximately 12,000 respondents a wide variety of questions on their finances. A comparison of OSB and CFM data reveals differences in the characteristics of bankrupt individuals and the households responding to the CFM survey. As shown in Table 1 , CFM respondents are more likely to be homeowners. Furthermore, they tend to fully own their homes, as relatively few of them have mortgages. This is likely because many CFM respondents are older, retired, and less likely to be unemployed, as seen from Table 3 .

It is difficult to get a full picture of CFM respondents' liability portfolios, given that the survey does not ask about "non-financial" debts, such as taxes owed, debts to individuals, payday loans etc. However, as shown in Panel B of Table 2, survey participants use more bank debt, while non-bank credit cards and other financial institutions are less prominent in their portfolios. While non-bank credit cards form $20 \%$ of all liabilities of bankruptcy filers, they correspond to around $23 \%$ of the "purely financial debt" portfolio in the CFM sample.

\section{Lender Presence, Information and Bankruptcy}

We present a model to highlight the link between soft information and default. We assume an economy with banks that live for three dates, $t=0,1,2$. Banks are risk neutral and, for simplicity, have a discount factor of 1 . We assume there is a representative bank. 
The economy is divided into different areas that are identical at date 0 . In order to operate in an area the bank must open at least one office of variable size in that area at date $0 .{ }^{3}$ At date 1 the bank makes its investment decisions (grant loans) and in date 2 it collects revenues.

The bank can open offices in all of the areas of the country. The main role of an office is to provide soft information about the borrower. This could be thought of as the ability to screen and/or monitor the loans that the bank makes in the area. Opening an office is a fixed, long term investment that takes one period to complete because it is time consuming for the bank to find a location, train the staff or reallocate existing employees, etc. Similarly, we also assume that closing an office takes one period to close an office. ${ }^{4}$ Hence, between dates 1 and 2 , the number of offices that the bank has in a given area is fixed.

In our simplified analysis with a single representative bank in ex ante identical areas, we assume that the bank decides on the size $S$ of the office it opens in each area. ${ }^{5}$ We assume that opening an office has a cost $c$ per unit of size, ${ }^{6}$ so the total cost of opening an office is $c S$. For simplicity we assume that the cost is equal through the areas.

Concerning the loans, we assume that all loans are identical ex ante. The probability of default of a given loan is $p=q-g(s)$, where $s$ is the soft information capture for each loan. The function $g(s)$ represents the effectiveness of soft information. We assume that the more soft information a bank obtains on a loan, the lower its probability of default $\left(g^{\prime}(s)>0\right)$ through better screening and/or improved monitoring. The effectiveness of soft information, however, is decreasing in intensity $\left(g^{\prime \prime}(s)<0\right)$, since it is harder to find additional valuable soft information if some soft information has already been obtained. ${ }^{7}$

The soft information capture of an office will depend on its size and on the amount of loans outstanding. As loans are identical, the office will exert the same level of soft information capture per loan. Hence, the actual amount of soft information capture per loan is $s=\frac{S}{L}$, where $L$ is the total amount of loans that a bank has in a given area.

At date 0 the bank has an estimate of the amount of loans that will be granted in a given area in date $1, \hat{L}=L_{R}+\varepsilon$, where $L_{R}$ is the actual amount of loans that can be granted in the area at date 1 and $\varepsilon$ is an estimation error with mean $0 .{ }^{8}$

The optimal size of a given office in an area is the solution of the bank's problem at date 0 given its estimate of loans.

$$
\underset{S}{\operatorname{Max}} \hat{L} \cdot R\left(1-q+g\left(\frac{S}{\hat{L}}\right)\right)-c S,
$$

\footnotetext{
${ }^{3}$ The size of the office is equivalent to the number of (identical) offices that a bank opens in a given area.

${ }^{4}$ The results of the model are similar if there is a cost to closing an office. This cost could be related to the cost of firing employees, legal actions etc.

${ }^{5}$ We leave aside competition among different banks in a given area. We assume that the bank receives loans independently of the strategies of the other banks in the area.

${ }^{6}$ employee, branch managers or per branches, depending on the relevant measure of soft information.

${ }^{7}$ Some extra conditions to guarantee an interior equilibrium are needed. Sufficient conditions are $g^{\prime}(0)=\infty$, $g^{\prime}(\infty)=0$. Also it is needed that $g(\infty)=q$.

${ }^{8}$ Another interpretation is that $\epsilon$ it is a demand shock that randomly affects some areas.
} 
where $R$ is the net return that the bank obtains if the loan does not default. The first order condition, which implicitly determines the desired soft information capture per loan, $\bar{s}$, is

$$
R g^{\prime}(\bar{s})-c=0
$$

Hence, at date 0 the bank is going to start an office of size $\bar{S}=\bar{s} \hat{L}$ to be completed by date 1 .

In date 1 the shock is realized and the actual amount of loans that the bank can grant $\left(L_{R}\right)$ may differ from the predicted amount of loans $(\hat{L})$. The bank has to decide the amount of loans to grant in period 1 , with its fixed office size $\bar{S}$ :

$$
\underset{L}{\operatorname{Max}} \operatorname{LR}\left(1-q+g\left(\frac{\bar{S}}{L}\right)\right)-c \bar{S}
$$

Given the fixed office size $\bar{S}$, the bank will find optimal to grant an amount of loans that is implicitly determined by the first order condition of the previous expression

$$
R\left(1-q+g\left(\frac{\bar{S}}{L}\right)\right)-g^{\prime}\left(\frac{\bar{S}}{L}\right) \frac{R \bar{S}}{L}=0 .
$$

It can be shown that it is optimal for the bank to grant more loans $\left(L^{*}\right)$ than predicted $(\hat{L})$ if it has the opportunity: $L^{*}>\hat{L}$.

Proof: Using equation (1) evaluated at $\hat{L}$, we obtain a positive value for equation (2):

$$
R\left(1-q+g\left(\frac{\bar{S}}{\hat{L}}\right)\right)-R g^{\prime}\left(\frac{\bar{S}}{\hat{L}}\right) \frac{\bar{S}}{\hat{L}}=\underbrace{R\left(1-q+g\left(\frac{\bar{S}}{\hat{L}}\right)\right)-c \frac{\bar{S}}{\hat{L}}}_{E \text { (profits per loan) }}>0
$$

Implicitly, banks' expected profits per loan are positive at date 0. Otherwise, the bank would profit more from a positive outside option.

If the bank grants $\hat{L}$ in loans, the first order condition in period 1 is not binding so the bank has an incentive to give more loans than the ones it initially expected. Hence, the total amount of loans that the bank actually grants will be $L=\min \left(L_{R}, \bar{L}\right)$, where $\bar{L}$ is the maximum amount of loans the bank is willing to make and is implicitly defined by equation (2).

However, if there is a very good shock, the bank might decide to violate this relationship $(L \neq \bar{L})$. This is because granting more loans, while increasing profits, also has the negative effect of reducing the soft information capture and thus increasing the probability of default of all the loans in the bank's portfolio.

The probability of default of a given loan at period 1 is:

$$
p=q-g\left(\frac{\bar{S}}{L}\right), \quad \text { with } \quad \frac{d p}{d L}=g^{\prime}\left(\frac{\bar{S}}{L}\right) \frac{\bar{S}}{L^{2}}>0
$$

Hence, we can conclude that higher amount of loans in an area results in lower soft information 
capture per loan, which leads to a higher default probability and vice versa. ${ }^{9}$

Importantly, the higher default probability does not work solely through the extensive margin. Although the bank makes more loans at date 1 than initially expected at date 0 , it is not these additional loans to potentially riskier borrowers that cause the increase in default probabilities. Rather, the default probabilities rise for all loans, including existing ones, indicating at least some intensive margin effect.

Based on the results of the model, we hypothesize that:

Hypothesis 1. Markets where lenders (banks) capture less soft information have higher bankruptcy rates. Furthermore, a key channel is the intensive margin.

Given the importance of branches in collecting and processing soft information, the "soft information capture" of lender $l$ with respect to borrower $b$ is defined as:

$$
\text { Soft } \text { Info }_{b l}=\frac{\text { Loans of borrower } b \text { with lender } l}{\text { No. of lender l's branches in borrower } b \text { 's neighborhood }} .
$$

This measure can be thought of as "number of loans per branch" for any borrower and when averaged over all the borrowers of a lender, it becomes the "number of loans per borrower per branch" (Soft Info $_{l}$ ). An increase in Soft Info ${ }_{b l}$ implies a decrease in a bank's use of soft information. While having a higher "loans per borrower" measure is potentially beneficial for the bank (the ability to monitor multiple accounts at once), having very few branches in an area suggests that the bank does not have the capacity to utilize this soft information.

Our measure of soft information capture is similar to the "credit card loans per bank employee" ratio used by Dick and Lehnert (2010), although we argue that it has a different interpretation in our context. Dick and Lehnert (2010) interpret their ratio as increased loan productivity due to banks adopting sophisticated credit scoring technologies. They then use this ratio to argue for the presence of an external margin mechanism behind hard information and higher bankruptcies. In our case, however, all Canadian lenders had adopted credit scoring technologies by the beginning of our sample period. Therefore, Soft $\mathrm{Info}_{l_{1}}>\mathrm{Soft} \mathrm{Info}_{l_{2}}$ is unlikely to capture the productivity difference between a lender that uses credit scoring versus a lender that does not. Instead, it captures a lender that uses hard information as a substitute for soft information $\left(l_{1}\right)$ versus a lender that uses hard and soft information as complements $\left(l_{2}\right)$, all else equal. ${ }^{10}$

\footnotetext{
${ }^{9}$ If we have a model with heterogenous banks, those that invest more in soft information would suffer more from having more loans. We could see this as a model in which banks in the first stage decide to invest more in soft or hard information

${ }^{10}$ A clear advantage of the Dick and Lehnert (2010) measure is that they use employee data at the bank-state level. We only have employee data at the province level, aggregated over all lenders. Loan officers per branch is relatively constant across the Canadian provinces.
} 


\section{Empirical Analysis}

\subsection{Local Market Definition}

Our main market definition is a "forward sortation area" (FSA), which is the first three digits of the six-digit Canadian postal code. For urban areas, a small or middle-sized city is usually covered by a single FSA, while larger cities have more than one FSA assigned to them. Out of the 1,610 FSAs in Canada, we drop those that are too sparsely populated (for example, industrial areas), too small (less than 2 square kilometers) or too large (more than 1,000 square kilometers). We use the remaining 1,224 FSAs. When considering the local banking market structure, we define the local banking market as the circular area within $x \in\{3,5,7\}$ kilometers of the centroid of an FSA. Data on bank branch locations is from the Financial Services Canada directory, which is produced by Micromedia ProQuest. ${ }^{11}$

\subsection{Baseline Regressions}

In order to test Hypothesis 1, we calculate "soft information capture" for each filer. This results in the following measure for borrower $b$, located in market $i$ at time $t$ :

$$
\text { Soft } \operatorname{Info}_{b i t}^{s}=\frac{\sum_{l=1}^{L_{b}} \text { Loans of borrower } b \text { with lender } l \text { at time } t}{\sum_{l=1}^{L_{b}} \text { No. of lender l's branches in market } i \text { at the beginning of } t} \text {. }
$$

Averaging over all borrowers in market $i$ at time $t$ yields the market-wide soft information capture:

$$
\text { Soft } \operatorname{Info}_{i t}^{s}=\frac{\sum_{b=1}^{B_{i t}} \text { Soft }_{\text {Info }}^{s}}{B_{i t}} .
$$

We calculate this measure using two different data sources (denoted using superscripts): data on bankruptcy filers from the OSB and survey data on all Canadian households from CFM. The number of outstanding loans of a bankruptcy filer may not be representative of a typical Canadian individual, as bankrupt individuals may have more loans than the rest of the population. Our OSB-based measure may therefore under-estimate the soft information capture by banks in a given market. Using data from the CFM survey largely alleviates this problem, although it raises other issues. Given the CFMs relatively small sample size, we have few respondents in some neighborhoods, causing our measure of soft information to be noisy. We try to solve this problem by eliminating from the analysis FSAs with too few respondents. In addition, since CFM participants tend to be older households with fully paid homes, our CFM-based measure may also not be representative of the borrowers in the Canadian population. Nevertheless, if both measures of soft-information yield similar results in our empirical analysis, we can be confident that the impact of these measurement challenges are small. Summary statistics for each measure are presented in Table 4.

\footnotetext{
${ }^{11}$ For more details on the branch location data, please see Allen et al. (2008)
} 


\section{[INSERT TABLE 4 HERE]}

To test hypothesis 1, the relationship between soft information and bankruptcy, we estimate the following regression:

$$
\ln \left(\text { Bankrupt }_{i t}\right)=\alpha \cdot \ln \left(\text { Soft Info }_{i t}^{s}\right)+\xi H H I_{m t}+\mu_{F S A, i}+\gamma_{t}+\epsilon_{i t},
$$

where $\ln \left(\right.$ Bankrupt $\left._{i t}\right)$ is the number of bankruptcy filings per 1,000 residents in $\operatorname{logs},{ }^{12} \mu_{F S A, i}$ is either a FSA-level fixed effect or a combination of twenty-one census variables that capture socioeconomic characteristics of the FSA, ${ }^{13}$ province fixed effects ${ }^{14}$, and two additional measures that are likely to play an important role in bankruptcy rates in an area. The first measure is financial literacy, which is the average of four individual scores computed using the 2003 International Adult Literacy and Skills Survey (IALSS) and the 2006 census. ${ }^{15}$ The second measure is the average share of non-bank firms on bankruptcy filers' portfolios, calculated using the number of debts for each filer. This variable captures market-specific factors, such as the prevalence of payday lenders or presence of unbanked persons, that are not measured by census variables. $\gamma_{t}$ captures year fixed effects.

We also include the branch-based Herfindahl-Hirschman Index at the local market level $\left(H H I_{m t}\right)$ in equation (3) to account for market concentration. In highly concentrated markets, consumers are more likely to hold multiple accounts with the same institution, which could make it easier for the lender to simultaneously monitor these accounts and engage in soft information collection. On the other hand, such monitoring may be difficult in competitive markets, where a customer may have accounts with many banks. Furthermore, it is possible that lack of competition can reduce the amount of credit in concentrated markets, leading to lower default rates (which can be thought of as an "extensive margin" effect). ${ }^{16}$

Since electronic filing began in 2003, we only estimate equation (3) for 2003-2007 when soft information capture is calculated using the OSB data. Furthermore, we drop the FSAs where either less than $25 \%$ of the filers electronically filed in year $t$ or there were fewer than 10 e-filers in

\footnotetext{
${ }^{12}$ Since population information is only available every five years, we interpolate population for the remaining years. Using fixed 2001 population for each FSA (and ignoring population growth) yields very similar findings (not shown).

${ }^{13}$ These include information on income, housing and rental costs, housing characteristics, age, and education.

${ }^{14}$ The type and amount of property that is exempt from seizures in case of bankruptcy varies across provinces. In Alberta, for example, the filer's equity in his/her principal home is exempt from seizure, while, during our sample at least, such an exemption was not available in other provinces.

${ }^{15}$ We convert this data from its original census dissemination area level used in Murray (2011) to the FSA-level. A census dissemination area is the smallest census aggregation area, roughly the size of a postal code. We match dissemination areas with postal codes and then average the literacy scores at the FSA level (weighted by the number of survey participants in each postal code). For more details on the IALSS and the computation of the literacy scores, please see Murray (2011). The four individual score include prose, numerical, document, and health literacy.

${ }^{16}$ Dick and Lehnert (2010) note that the impact of competition on default is ambiguous; monopolists can also afford to have low lending standards and absorb the credit losses via the rents they earn.
} 
the market. ${ }^{17}$

When using the CFM survey to calculate soft information capture, we estimate equation (3) for the entire CFM sample (1999-2007). ${ }^{18}$ However, in order to be consistent with the specifications using the OSB sample, we also estimate this equation for 2003-2007 and use the same selection criteria described above. In all regressions we drop all FSAs where the number of lenders per 1,000 people is greater than 10 to make sure that business districts with few residents do not drive the results. Given the relatively few number of lenders in Canada, an area with 10 active lenders per 1,000 persons is likely to represent financial districts in the downtown areas of the major Canadian cities. ${ }^{19}$

The results of equation (3) are given in Table 5. Our results suggest that bankruptcy rates are higher in markets where banks capture less soft information. Concentrating on the 5KM specifications, the estimate on in column (1) suggests that a one standard deviation decrease in a banks use of soft information is correlated with a $10.3 \%$ increase in the bankruptcy. The estimate on soft information in column (2) where we use FSA census controls rather than FSA fixed effects are slightly smaller - a one standard deviation decrease in a banks use of soft information is correlated with a $6.1 \%$ increase in the bankruptcy. The specification with census controls has substantially worse fit than the fixed effect specification, and the omitted variable(s) is likely putting downward pressure on the estimate. The estimate in columns (3)-(6) all use CFM data, and the correlation between soft information and bankruptcy range from $4.2 \%$ and $9.2 \%$. These results are robust to the size of the neighborhoods, ranging from $3 \mathrm{KM}$ to $7 \mathrm{KM}$.

[INSERT TABLE 5 HERE]

If the soft information gathered through branches did not matter, then we would expect our measure of soft information capture to have no impact on bankruptcy rates. If credit scoring is a perfect substitute to soft information, then the number of loans per borrower should not play any role in bankruptcies. After all, the concept of "loans per borrower" implies the presence of intensive margin effects, which goes against much of the existing literature. Furthermore, if the lack of a branch presence can easily be substituted away by credit scoring (as argued by Petersen and Rajan (2002)), then the number of branches at the local level should not play any role in bankruptcy/default decisions. If a variable such as "loans divided by total number of bank employees" was found to be positively related to bankruptcies, then the possibility of an extensive margin

\footnotetext{
${ }^{17}$ Since e-filing was not introduced at random, these restrictions could lead to a degree of selection bias. We account for this possibility with a simple Probit selection equation where the probability of e-filing is a function of home-ownership, income, local unemployment rates, house values, and province fixed effects. The Probit is estimated separately for each year (since vast majority of the FSAs have Efile it $=1$ by 2006 and all of them fit this criteria in 2007) and the resulting inverse Mills ratios are used as an explanatory variable in equation (3). The inverse Mills ratio tends to be insignificant, suggesting that there is no selection based on unobservables. Therefore, we do not present the results here. Results are available upon request.

${ }^{18}$ Since the "share of non-bank firms in filers' portfolios" variable discussed above can only be calculated using OSB data (CFM does not contain non-financial debt), it is excluded from this specification.

${ }^{19}$ Our main findings do not change if these very few FSAs are included in the sample.
} 
effect (through the increased productivity argument of Petersen and Rajan (2002) and Dick and Lehnert (2010)) may still exist. In our case, however, neither the "loans per borrower" nor the "per local branch" components of Soft Info ${ }_{i t}$ is associated with the extensive margin/labor productivity explanation of higher bankruptcies. Therefore, we argue that the lack of soft information use at the local level at least partially contributes to higher default rates through an intensive margin effect.

Finally, the results in Table 5 also provide some limited support to the argument that defaults are lower in more concentrated markets. We are, however, unable to determine whether any possible links between $H H I_{m t}$ and bankruptcies are through credit rationing or through the concentration of different types of accounts in a few lenders.

\section{$5 \quad$ Mergers, Soft Information and Bankruptcies}

The analysis to this point has concentrated on the ability of banks to capture soft information through their branches. Our main measure of soft information, Soft Info ${ }_{i t}$, however, may be endogenous, given banks' endogenous branching and lending decisions. That is, there might be a concern that banks close branches in neighborhoods with high bankruptcy rates (leading to a higher Soft Info $_{i t}$ ) and not that closures leads to bankruptcy. Similarly, banks may reduce the amount of credit supplied to high bankruptcy neighborhoods. We address each issue in turn.

In order address these issues, we now illustrate how an increase in Soft Info $i t$ (i.e. loss of soft information) through an exogenous event (such as a merger) can trigger more bankruptcies by increasing the default probabilities of existing borrowers. Using the exogenous variation in branch closures caused by a merger helps alleviate some of the endogeneity concerns related to branches and our soft information capture variable. This is similar to the approach of Dick and Lehnert (2010), who use banking sector deregulation in the U.S. as an exogenous event.

We use two incidences of merger/acquisition activity that occurred during our sample period. The first event is the acquisition of Canada Trust by Toronto-Dominion Bank (TD) in 2000. The second event involves the purchase of Laurentian Bank's branches outside of the province of Québec (and Ottawa, Ontario) by TD-Canada Trust in 2003. ${ }^{20}$ Both of these mergers were agreed upon at a Canada-wide level between banks with national branch networks. Hence, any variation in the market structure resulting from these mergers will be exogenous at the local, FSA-level. This identification strategy has been previously used in a number of different industries, including banking, by Hastings (2004), Hortacsu and Syverson (2007), Houde (2011), and Allen et al. (2012),

These mergers are important for our analysis given their impact on information. Panetta et al. (2009) find that mergers can improve information gathering, especially if a large bank with hard information screening ability acquires a small bank which relies more on soft information. Furthermore, since a merger increases the size and hierarchical structure of a bank, it can also

\footnotetext{
${ }^{20}$ Although an acquisition, this event will be also referred to as a "merger" for simplicity.
} 
reduce the use of soft information within the organization (Stein (2002) and Berger et al. (2004)). The analysis of these mergers can therefore help determine the impact of switching to a hard information-only model on bankruptcies.

\subsection{Overview of the Mergers}

\subsubsection{TD - Canada Trust}

TD's acquisition of Canada Trust was the largest of a string of mergers between banks and trust companies during the 1990s. This merger activity was triggered by a change in the Canadian Bank Act in 1992, which allowed bank to acquire trust companies. Until that point, trust companies (which can roughly be compared to Savings and Loans in the United States) played an important role in the retail market. ${ }^{21}$

At the time of the merger (February 2000), TD and Canada Trust operated around 900 and 440 branches, respectively. There were some important differences in how these two banks conducted their business. Canada Trust was well-known as a community-based institution that depended on a branch-based business model, with almost $90 \%$ of its branches concentrated in three provinces (Ontario, Alberta and British Columbia). Canada Trust was also known for its extended business hours, in particular the "8 to 8 six days straight" service at its branches. ${ }^{22}$ TD was a larger institution, with more sparsely distributed branches (for example, only $76 \%$ of its branches were in Ontario, Alberta and British Columbia). A major reason for TD Bank's purchase of Canada Trust was to improve its customer-based banking. The merger cost roughly $\$ 8$ billion, and TD was asked by the Canadian Competition Bureau to divest its branches in three markets in Ontario as a condition of approval for the merger. ${ }^{23}$

For the purposes of this study, the TD-Canada Trust merger has the interesting feature of a bank known for branch-based business model being incorporated into an institution that depended more on hard information. If some of the soft information used by Canada Trust prior to the merger was lost during the reorganization of the newly merged institution, default rates of customers could have been affected. Indeed, it does appear that some customers switched banks, either by choice or due to their inability to continue borrowing from TD-Canada Trust after the merger. In the CFM survey, $20 \%$ of the consumers who identified Canada Trust as their "main financial institution" in 1999 switched financial institutions by 2003.

\footnotetext{
${ }^{21}$ Other examples of such bank-trust mergers are Royal Bank of Canada-Royal Trust (1993), Bank of MontrealHousehold Trust (1995), CIBC-FirstLine Trust (1995), and Scotiabank-National Trust (1997). We don’t analyze these mergers because of data limitations.

${ }^{22}$ http://www.td.com/about-tdbfg/corporate-information/tds-history/we-take-pride-in/history.jsp, accessed September, 2011.

${ }^{23}$ These three markets were Brantford, ON, Kitchener, ON and Port Hope, ON.
} 


\subsubsection{TD - Laurentian Bank}

In August 2003, Laurentian Bank announced its intention to sell its branches outside of the province of Québec and Ottawa, Ontario. The bank's stated aim was to concentrate its retail business in Québec, the bank's home province and the market where it had the greatest presence. TD - Canada Trust, which already had the third largest branch network $(1,100)$ in Canada, bought these 57 branches. The Laurentian Bank branches that were sold to TD-Canada Trust were located in five provinces. $^{24}$

The TD-Laurentian branch sale is of interest to this study, given its unique nature. Despite the relatively few branches that were involved, it represents the exit of a regional bank from its peripheral markets. Given that Laurentian Bank is based in Québec, with its cultural and linguistic differences from Central and Western Canada, it is clear that there was a great distance between the bank's branch network and headquarters. Relative to the Big 6 banks, Laurentian Bank also appears to have had more of a relationship-based business model at the time of the sale, as stated in the bank's annual report: "It is essential that we follow our customers wherever they move, and be present in areas where our services can be appreciated. We can thus considerably build the loyalty of our customer ... and become the principal banker of even more Quebeckers" ${ }^{25}$ It is likely that soft information-based monitoring through branches played a role in Laurentian's business strategy.

This merger is thus similar to the TD-Canada Trust merger since a lender more dependent on monitoring though branches is replaced by a lender that relies more on hard-information.

\subsection{Empirical Setup of the Merger Analysis}

Bank mergers have several effects. First, there is a reduction of the number of lenders active in the market. Second, the newly merged entity closes "overlapping branches" to cut costs. Third, the larger bank created by the merger could encounter difficulties using and transmitting soft information, leading to a reduction in lending to soft information-dependent borrowers (Berger et al. 2004).

Based on the results discussed in Section 4, the impact of the newly merged entity's actions on bankruptcy rates is ambiguous. If the bank closes branches but continues to lend the same amount, through its consolidated branches in the area, then its soft information capture will fall and bankruptcies should be higher. If, however, the bank closes branches and decreases its lending, then the overall effect on soft information capture is unclear.

In addition to the actions of the newly merged entity, the response of the remaining incumbents could also play a role in the impact of these acquisitions on bankruptcy rates. Branch closures, or

\footnotetext{
${ }^{24}$ The five provinces were: Alberta, British Columbia, Manitoba, Ontario and Saskatchewan. In Manitoba and Saskatchewan, Laurentian had only one branch each. The largest number of branches sold were located in Ontario. Laurentian's branches in Ottawa were excluded from the sale, presumably due Ottawa's location near the border of Québec, and its economic connections to Québec communities.

${ }^{25}$ Laurentian Bank 2003 Annual Report, page 12.
} 
any reduction of lending by the merged entity can prompt its competitors to increase their lending and/or to open new branches (Berger et al. (2004) and Damar (2007)). If the remaining incumbents increase their lending without opening new branches, then their overall soft information capture in the affected markets may fall and bankruptcies may rise. However, if both lending and the number of branches of the incumbents rise, the impact on soft information capture should be ambiguous.

In order to examine the impact of these mergers on consumer bankruptcies, we first determine the treatment and control groups. Given that most of the discussion has concentrated on markets where the two merging banks' branch networks overlap, the treatment group is the set of markets where both merging banks have at least one branch. The control group is the set of remaining markets where either one of the merging banks have a branch or none of the merging banks have any presence. The separation of the markets in the sample into the treatment versus control groups for both mergers is illustrated in Figure 3.

\section{[INSERT FIGURE 3 HERE]}

As seen in Figure 3, the FSAs in our sample are divided into four categories. "A-B" are the markets where both merging institutions had at least one branch within $x \in(3,5,7)$ kilometers from the centroid of the FSA. Markets "A" and "B" are those where only one of the merging institutions were present within $x \mathrm{~km}$. Markets "O" are those where neither merging institution had a branch. The treatment group is the set of "A-B" markets, since these are most directly impacted by the merger. Since there was branch network overlap in these FSAs, closure of branches by the newly merged institution is a likely possibility. Furthermore, these areas lost a lender, since two of the

lenders that were active in these markets consolidated into one. Markets in "A", "B" and "O" are the control markets since they are not directly affected by the merger.

\subsubsection{Mergers and Bankruptcy Rates}

The initial step is the link between merger activity and bankruptcy rates in markets that were affected by the merger. This is done by estimating the following regression:

$$
\text { Bankrupt }_{i t}=\alpha_{1} \cdot \text { Treatment }_{i} \cdot \text { Post }_{t}+\alpha_{2} \cdot \text { Post }_{t}+\alpha_{3} \cdot \text { Treatment }_{i}+\mu_{F S A, i}+\gamma_{t}+\epsilon_{i t},
$$

where Treatment $_{i}$ is a dummy variable for the "A-B" markets (and is absorbed into the FSA fixed effect). Post $t_{t}$ takes the value of one for the post-merger period and 0 otherwise. Treatment ${ }_{i}$. Post $t_{t}$ captures the treated markets in the post-event period and is the main variable of interest.

In calculating the pre- and post-merger periods, we eliminate the year of each merger from the analysis (2000 for TD-Canada Trust and 2003 for TD-Laurentian). Given that the mergers took place during the year, including the merger year in the analysis is not practical. We then consider two different specifications for the pre- and post-merger "windows": (i) two years before 
and two years after the merger, and (ii) two years before and three years after the merger. We include (ii) in our analysis because bankruptcy decisions are not instantaneous and the impact of the mergers on bankruptcies may take time to appear. The downside of having a long post-event window is the possibility of including factors not related to the merger, which can confound the results. Specification (i), however, attempts to minimize such confoundedness.

\section{[INSERT TABLE 6 HERE]}

The results presented in Table 6 suggest that the TD-Canada Trust merger is associated with higher bankruptcy rates in the most affected markets. The merger led to an increase in the the average bankruptcy rate by 3\%-5.5\%, depending on the specification. The TD-Laurentian merger is also associated with an increase in bankruptcy rates, of about 3.8\%-7.5\%. The impact of these mergers, therefore, is an increase in the number of bankrupts of about 1-3 people per 10,000, depending on the merger and the specification. This is not insignificant, given the low bankruptcy rates in Canada, with less than 100,000 Canadians filing per year.

These finding, however, could be due to a number of different factors. Bankruptcy rates may rise if the merged institution continues to lend but closes some branches and uses less soft information. Alternatively, the merged institution may reduce its lending by a significant amount and, if the remaining incumbents don't react, the overall quantity of credit supply will fall. Lacking access to credit, some households may not be able to deal with temporary liquidity shocks and are forced into bankruptcy. Finally, it could be the case that the degree to which the merged institution captures soft information remains the same, but its competitors react in a way that reduces their use of soft information, leading to higher bankruptcies. In order to disentangle which of these scenarios apply to our two mergers, two other factors need to be examined: (1) the impact of the mergers on branching and (2) the link between the merger activity and the overall supply of credit.

\subsubsection{Mergers and Availability of Branches}

To investigate the possibility that the merger invited entry and/or increase in the branch presence of the remaining incumbents (Damar 2007), we estimate the following regression:

$$
\text { Branches }_{i t}=\alpha_{1} \cdot \text { Treatment }_{i} \cdot \text { Post }_{t}+\alpha_{2} \cdot \text { Post }_{t}+\alpha_{3} \cdot \text { Treatment }_{i}+\mu_{F S A, i}+\gamma_{t}+\epsilon_{i t},
$$

where Branches Bt $_{i}$ is the number of bank branches per 1,000 residents within $x \mathrm{~km}$ of FSA $i$, at the beginning of year $t .{ }^{26}$ The results from most specifications in Table 7 confirm that the treated markets experienced a decrease in the number of branches per capita. The results suggest that TD-Canada Trust did close some of its overlapping branches and the reactions of competitors was insufficient to bring the number of branches back to its pre-merger levels.

\footnotetext{
${ }^{26}$ For the TD-Canada Trust merger, we exclude the 21 FSAs located in the three geographical markets where TD was required to divest its branches as a condition of the approval of the merger.
} 


\section{[INSERT TABLE 7 HERE]}

\subsubsection{Mergers and Credit Supply}

Another concern is the evolution of credit supply in treated markets. For this, we use the CFM survey, which includes sections on all type of loans, including mortgages and credit cards. Households report the institution holding the loan, the interest rate on the loan, the term of the loan, whether the rate is fixed or variable, the payment frequency, the amount of each payment and the current balance of the loan. The survey, however, does not ask the respondents when the loan was initially issued. Nevertheless, given the available information we are able to calculate the present value of the stream of payments, which should approximate the original value of the loan. ${ }^{27}$ We can then approximate when the loan was issued by comparing the original amount to the stated current balance. A discussion of the methodology, including our modified market definition, is contained in the Appendix.

Using the constructed data on credit supply, we calculate the "new credit issued per capita" at the market level $\left(\right.$ Credit $\left._{j t}\right)$ and estimate the following regression:

$$
\text { Credit }_{j t}=\alpha_{1} \cdot \text { Treatment }_{j} \cdot \text { Post }_{t}+\alpha_{2} \cdot \text { Post }_{t}+\alpha_{3} \cdot \text { Treatment }_{j}+\mu_{\text {Market }, j}+\gamma_{t}+\epsilon_{j t} .
$$

Unlike the FSA-based definition, Treatment ${ }_{j}$ only takes into consideration whether both merging banks were present within a larger market $j$. The pre- and post-merger periods are constructed as two years before and two years after the event, with the year of the merger excluded. We also limit the sample to markets where we have data for at least three out of the four years included in the analysis.

\section{[INSERT TABLE 8 HERE]}

Results are presented in Table 8 and suggest that neither the TD-Canada Trust or TD-Laurentian Bank merger had an impact on the overall supply of credit. Re-defining the merger window as two years before and three years after does not yield a major change in these findings. Overall, it appears that despite the decrease in the number of branches, credit supply remained unchanged in the markets affected by the two mergers.

We can further break-down the zero aggregate change in credit supply into a direct effect (merging parties) and an indirect effect (rivals). We calculate the market share of TD-Canada Trust at the "larger market" level, using the number of loan products reported in CFM. We calculate the total number of credit cards, loans, mortgages and personal lines of credit in each market and

\footnotetext{
${ }^{27}$ This calculation is subject to many caveats, including whether or not the household is paying more than the required amount. This method is meant to be an approximation rather an a definitive registry for household loans in Canada. We do not use data on credit cards and personal lines of credit since we are unable to identify when those products were first issued.
} 
use these figures to find the market share of TD-Canada Trust before and after the merger. ${ }^{28}$ For the pre-merger period, individual market shares of TD and Canada Trust are added to create a market share for "quasi TD-Canada Trust". ${ }^{29}$ We are unable to calculate this market share for 1998, since CFM data starts only in 1999. Therefore, the pre-merger period consists of 1999, while the post-merger period is defined as 2001-2002. Using these market shares, we estimate:

$$
\text { Share }_{i t}=\alpha_{1} \cdot \text { Treatment }_{i} \cdot \text { Post }_{t}+\alpha_{2} \cdot \text { Post }_{t}+\alpha_{3} \cdot \text { Treatment }_{i}+\mu_{\text {Market }, i}+\gamma_{t}+\epsilon_{j t} .
$$

The results in Table 9 clearly suggest that TD-Canada Trust decreased its lending in treated markets. This complements the decision to close overlapping branches; as some branches are eliminated, some households will no longer borrow from the merged bank. This could be due to soft information being lost, or due to competitors' efforts to steal customers from the merged bank. Nevertheless, the fact that the overall credit supply remained unchanged while the merged bank decreased its lending implies that the remaining incumbents made more loans. While they were increasing their lending, however, they did not sufficiently increase their soft information gathering capacity by opening additional branches, given the adjustment costs of opening branching. As a result, their soft information capture fell (higher Soft $\mathrm{Info}_{l}$ ), contributing to higher bankruptcy rates.

\section{[INSERT TABLE 9 HERE]}

Overall, the merger analysis results seem confirm Hypothesis 1. Given that the quantity of credit supplied did not change in the affected markets, the increase in the bankruptcy rates must have been caused by an increase in the default probability of existing borrowers (i.e. the "intensive margin"). Furthermore, it appears that the higher bankruptcy rates were triggered by a reallocation of borrowers between banks. Given that all of the lenders involved used credit scoring technology during the post-merger periods, the loss of soft information regarding the customers that switched banks is the most likely explanation for this higher bankruptcy rates. This is strong evidence in favor of the complementarity of soft information and hard information.

\section{Robustness}

\subsection{Bank-Market Level Regressions}

A potential concern in the estimation of (market-level) equation (3) is that it does not use any bank-level information. For example, a few large outliers in Soft Infobmt can skew the average and

\footnotetext{
${ }^{28}$ This analysis is not performed for the TD-Laurentian merger, given Laurentian's small pre-merger market share in affected markets.

${ }^{29}$ We weight each observation based on the total number of loan products in the market, since the number of loans/survey respondents in each market can differ substantially by market size.
} 
result in a high Soft Info $_{m t}$. Estimating a variation of equation (3) at the bank-market level can alleviate these concerns, while allowing us to control for individual bank-specific fixed effects.

The soft information capture of an individual bank in market $i$ at time $t$ is relatively easy to construct. Consider:

$$
\text { Soft Infolbit }=\frac{\text { Loans of borrower } b \text { with lender } l \text { in market } i \text { at time } t}{\text { No. of lender l's branches in market } i \text { at the beginning of } t} \text {, }
$$

which is loans per person per branch at the borrower-lender level. Averaging this across all borrowers of lender $l$ in market $i$ yields soft information capture at the bank-market level: Soft Infolit.

Constructing the appropriate dependent variable (bankruptcy filings at the bank-market level) requires combining OSB filing data with CFM data. The desired variable is "percentage of lender l's customers in market $i$ who filed for bankruptcy." We first identify a "main bank" for each filer, to which the filer owes the largest number of loans (such as mortgages, credit cards, student loans, etc.). If the lender owes the same number of loans to more than one bank, we use the total amount owed as the tie-breaker. In this way we uniquely link most filers with a single bank.

We determine the overall number of households whose main bank is lender $l$ through the CFM survey. We apply the same criteria as above and identify the household's main bank. Combining the two data sets, however, presents a challenge. While the OSB data represents the universe of bankruptcy filings, CFM is a survey. Although CFM includes population weights, these are calculated for the national-level. Furthermore, OSB filings are done at the individual level, while CFM is a household survey. Nevertheless, we combine the OSB and CFM data to calculate:

$$
\text { File } \text { Share }_{l i t}=\frac{\text { Number of bankruptcy filers in market } i \text { whose main bank is } l}{\text { Weighted number of households in market } i \text { whose main bank is } l} \text {. }
$$

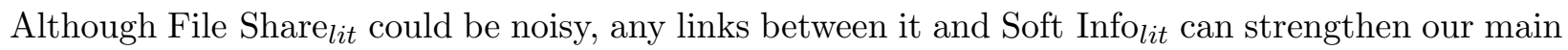
conclusions. We investigate such links by estimating the following regression:

$$
\ln \left(\text { File Share }_{\text {lit }}\right)==\alpha \cdot \ln \left(\text { Soft Info } \text { Iit }_{1}\right)+\xi H H I_{m t}+\mu_{F S A, i}+\Theta_{B a n k, l}+\gamma_{t}+\epsilon_{l i t} .
$$

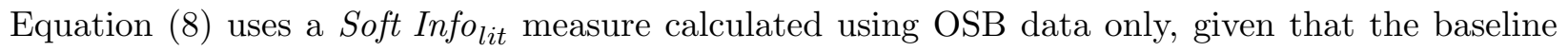
regression findings for OSB versus CFM-based Soft Info $_{\text {lit }}$ were quite similar. The dependent variable $\ln \left(\right.$ File Share $\left._{l i t}\right)$ is the log-transformed version of File Share lit $_{\text {. }}$.

[INSERT TABLE 10 HERE]

As seen in Table 10, the estimation of equation (8) yields similar results to our baseline analysis.

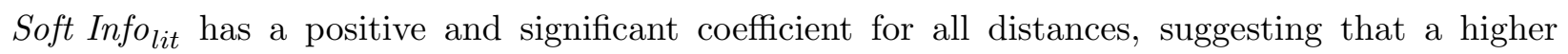
proportion of a bank's customers file for bankruptcy if the bank does not capture soft information. 


\subsection{Loan per Branch Regressions}

Another robustness check involves re-defining Soft Info $i t$ as the average "loans per branch" at the market level and re-estimating equation (3). We do this for all specifications, although the results where census control variables are included instead of market fixed effects are not reported.

[INSERT TABLE 11 HERE]

The use of "loans per branch" as a measure of soft information capture does not seem to significantly alter our results. Soft Info ${ }_{i t}$ still has a positive and significant coefficient for most of the specifications that use the 2003-2007 sample, although the findings for the 1999-2007 CFM sample are weaker. Nevertheless, these results broadly confirm our general conclusions. Regardless of how its measured, areas where banks' fixed soft information generating capacity is thinly stretched, bankruptcies are higher.

\section{Conclusion}

We analyze the relationship between soft-information and household bankruptcies in Canada. Since soft information is usually gathered through branches, we interpret the widespread closures of branches during our sample period as banks substituting away from soft-information and towards hard information. We find that in markets where soft information capture is low (i.e. banks have too many loans per branch to be able to gather and process soft information effectively), bankruptcy rates are higher. We confirm these findings by using two large mergers as exogenous variation in the branch network structure at the local level.

Unlike the existing literature on consumer bankruptcies, we do not find that the increase in bankruptcies is caused by more (and riskier) households receiving credit in these markets. On the contrary, our merger analysis suggests that in areas that were effected by the merger, the quantity of credit supplied was unchanged while bankruptcies rose. Given that all lenders in Canada use hard-information (i.e. credit scoring), the increase in bankruptcies without a change in the amount of credit supplied suggests a role for soft-information in preventing defaults. The presence of this soft-information (or intensive margin) channel is the main contribution of this study.

The relationship between soft information and consumer bankruptcies has policy implications regarding how banks make lending decisions while keeping their costs low. Some of the existing literature on household credit has argued that hard-information is a perfect substitute for softinformation and is also more cost efficient (since it doesn't require any branches). Our findings imply that soft-information and hard-information are more likely to be complements than substitutes. Our estimates suggest that a one standard deviation decrease in the use of soft information can lead up to a $10 \%$ increase in bankruptcies. Substituting away from soft-information can therefore lead to poor lending decisions and higher household bankruptcies. 


\section{References}

Agarwal, S., B. Ambrose, S. Chomsisengphet, and C. Liu (2012). The role of soft information in a dynamic contract setting: Evidence from the home equity credit market. mimeo.

Allen, J., R. Clark, and J. F. Houde (2008). Market structure and the diffusion of e-commerce: Evidence from the retail banking industry. Bank of Canada Working Paper No. 2008-32.

Allen, J., R. Clark, and J. F. Houde (2012). Price competition and concentration in search and negotiation markets: Evidence from mortgage lending. Bank of Canada working paper No. 2012-4.

Berger, A. N., S. D. Bonime, L. G. Goldberg, and L. J. White (2004). The dynamics of market entry: The effects of mergers and acquisitions on entry in the banking industry. Journal of Business 77, $797-834$.

Damar, H. E. (2007). Does post-crisis restructuring decrease the availability of banking services? The case of Turkey. Journal of Banking \& Finance 31, 2886-2905.

Dick, A. and A. Lehnert (2010). Personal bankruptcy and credit market competition. The Journal of Finance 65, $655-686$.

Domowitz, I. and R. Sartain (1999). Determinants of the consumer bankruptcy decision. The Journal of Finance 54, $403-420$.

Edelberg, W. (2006). Risk-based pricing of interest rates for consumer loans. Journal of Monetary Economics 53, $2283-2298$.

Freedman, C. and W. Engert (2003). Financial developments in canada: Past trends and future challenges. Bank of Canada Review, 3 - 16.

Hastings, J. (2004). Vertical relationships and competition in retail gasoline markets: Empirical evidence from contract changes in Southern California. American Economic Review 94, 317328.

Hortacsu, A. and C. Syverson (2007). Cementing relationships: Vertical integration, foreclosure, productivity, and prices. Journal of Political Economy 115, 250-301.

Houde, J.-F. (2011). Spatial differentiation and vertical mergers in retail markets for gasoline. Forthcoming, American Economic Review.

Hyytinen, A. and O. Toivanen (2004). Monitoring and market power in credit markets. International Journal of Industrial Organization 22, 269-288.

Keys, B., T. Mukherjee, A. Seru, and V. Vig (2010). Did securitization lead to lax screening? Evidence from subprime loans. Quarterly Journal of Economics 125, 307 - 262.

Livshits, I., J. MacGee, and M. Tertilt (2011). Costly contracts and consumer credit. NBER working paper 17448 . 
Loutskina, E. and P. Strahan (2011). Informed and uninformed investment in housing: The downside of diversification. Forthcoming Review of Financial Studies.

Marketing, L. (2002). A study about the financial situation and lifestyles of canadians who have declared bankruptcy between january 1,1996 to december 31, 1998. For l'Association coopérative d'économie familiale du Nord de Montréal.

Murray, S. (2011). Financial literacy: A conceptual review. Research paper prepared for the Task Force on Financial Literacy, Canadian Council on Learning.

Panetta, F., F. Schivardi, and M. Shum (2009). Do mergers improve information? Evidence from the loan market. Journal of Money, Credit and Banking 41(4), 673-709.

Petersen, M. and R. Rajan (2002). Does distance still matter? The information revolution in small business lending. The Journal of Finance 57, 2533-2570.

Sapienza, P. (2002). The effects of banking mergers on loan contracts. The Journal of Finance 57, $329-367$.

Serra, J. (2008). Economic rehabilitation: Understanding the growth in consumer proposals. Office of the Superintendent of Bankruptcy Research Paper.

Stein, J. C. (2002). Information production and capital allocation: Decentralized versus hierarchical firms. The Journal of Finance 57, 1891-1921. 


\section{Appendix: Constructing Credit Supply}

To construct a measure of credit supply we approximate when a household loan was issued by comparing the original amount to the stated current balance. We use this methodology for 12 years of CFM surveys (1999-2010) and identify the loans and mortgages that appear to have been originally issued in each year between 1999 and 2006. Aggregating the original loan amounts at a market level forms our "quantity of credit supplied" data. Even though the CFM survey includes population weights, we still do not have sufficient survey respondents to calculate credit supply at the FSA level. Instead, we construct a somewhat larger market measure in order to calculate the supply of credit.

This larger market definition is based on Canada Post's definition and usage of FSAs. Most municipalities in Canada are served by more than one FSA, while small urban and rural areas are covered by a single FSA. The number of FSAs that cover a municipality ranges from two to 156 . We treat municipalities that are covered by 13 or fewer FSAs to be a single market. The remaining large urban areas that are covered by 14 or more FSAs (there are 15 such municipalities) are divided into sub-markets consisting of anywhere between 7 and 13 FSAs. ${ }^{30}$ For example, the Greater Toronto Area, which consists of 156 FSAs, is divided into 18 such sub-markets. The quantity of loans supplied data from CFM is aggregated at this market level. Overall, there are 632 markets with reliable credit supply data.

Given the nature of CFM-based methodology, the approximated issue years of our sample is somewhat skewed. This is because we can only draw on 5 years of CFM surveys to identify loans that were issued in 2006 (2006-2010), while we can use all 12 years of CFM surveys to identify loans that were originated in 1998. Accordingly, we adopt three different approaches:

- Stack all year-market observations (Whole Sample)

- Identify the year between 1999 and 2006 with the lowest number of loans identified from CFM and randomly sample the same number of loans from all other years to create a sample with a uniform number of loans (Sampling Method)

- For each year $t$ of CFM only take the loans identified as being made in $t$ through $t-2$ and leave out the rest (Rolling Method)

\footnotetext{
${ }^{30}$ While dividing these cities into sub-markets we took care to pay attention to obvious divisions between different parts of cities, such as major highways, rivers, bays, etc.
} 
Figure 1: Consumer bankruptcies and proposals per 1,000 adults in Canada (1987-2008)

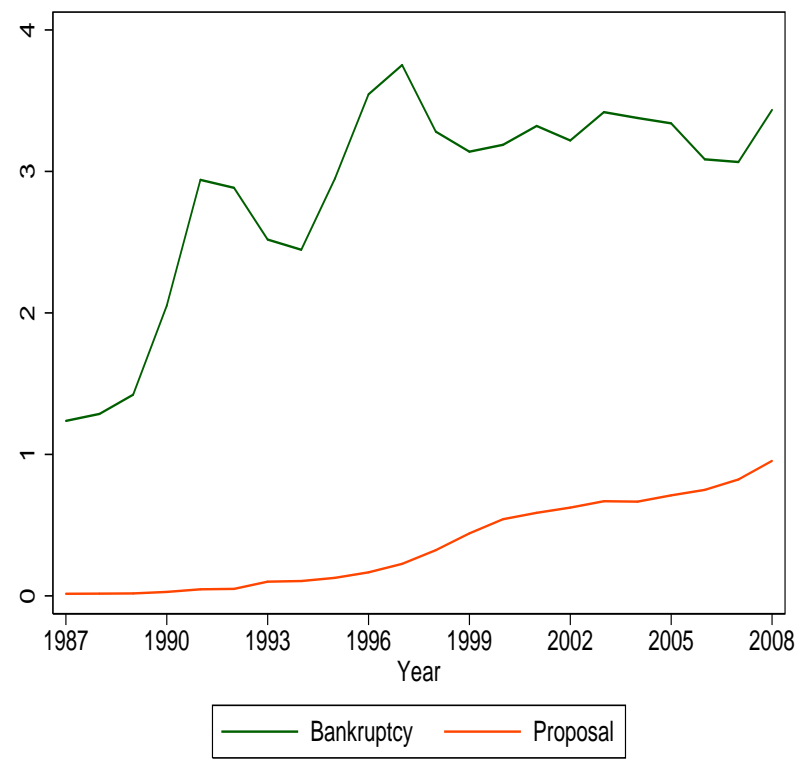

Figure 2: Annual growth rates of bankruptcy filings at the FSA level (1998-2007)

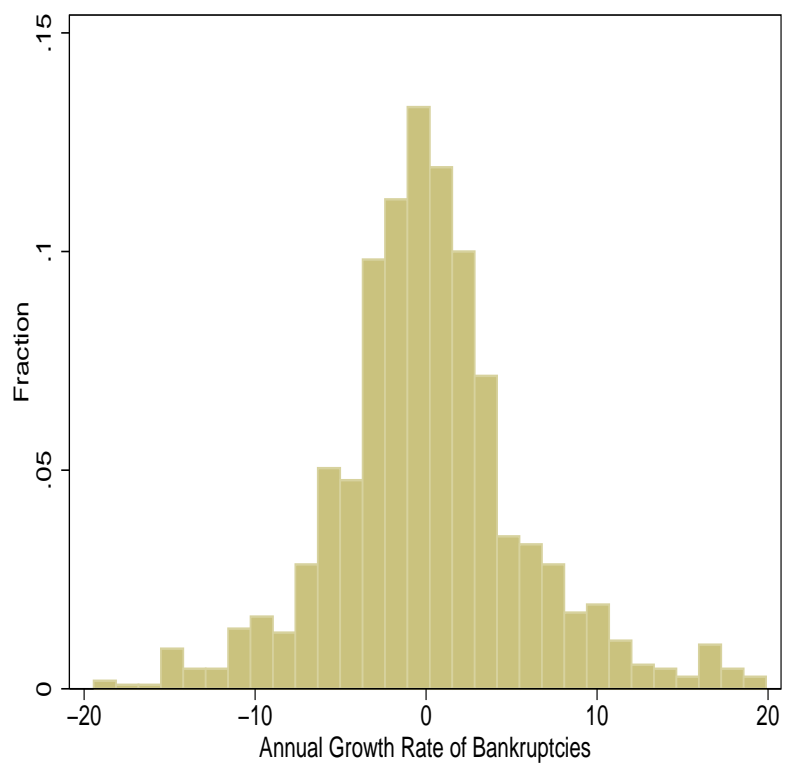


Figure 3: Division of the markets (FSAs) into "treatment" vs. "control" groups for (i) TD's acquisition of Canada Trust, and (ii) Laurentian Bank (LB) selling some of its branches to TD. The "treatment" group is "A-B" and the "control" group consists of "A", "B" and "O". The number of FSAs in each category is provided for the year immediately preceding the acquisition (2000 for TD-Canada Trust and 2002 for TD-LB), using a $5 \mathrm{~km}$ radius around the centroid of the FSA. For the TD-LB sale, the FSAs in Quebec and Ottawa, ON were excluded from the analysis, since LB did not put these branches on sale.

\section{Panel i: TD - Canada Trust Merger Panel ii: TD - LB Acquisition}
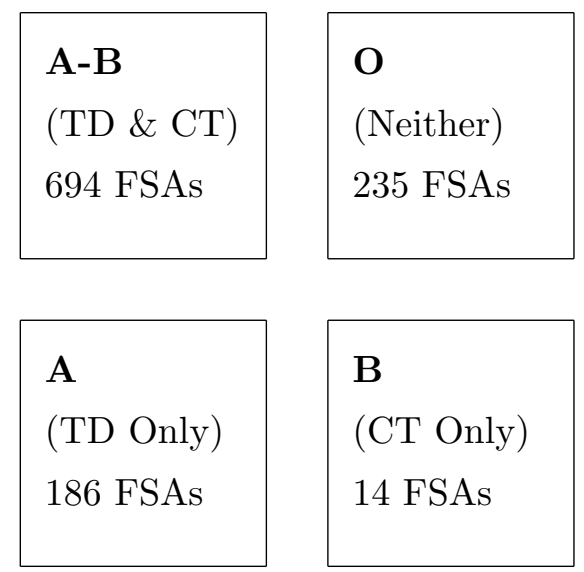

\begin{tabular}{|l|}
\hline B \\
(CT Only) \\
14 FSAs
\end{tabular}
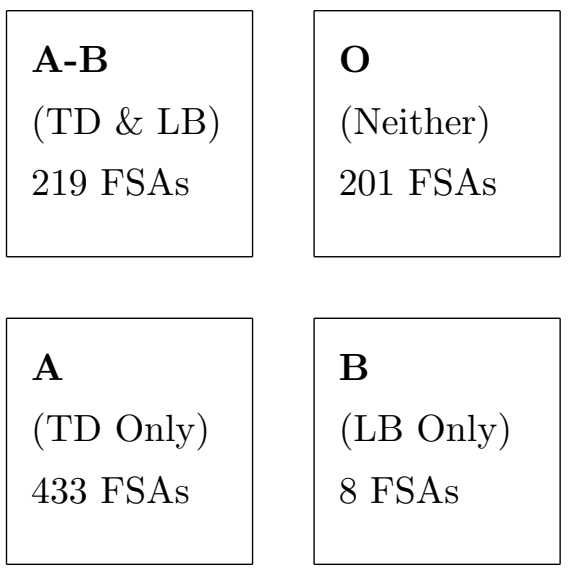

B

(LB Only)

8 FSAs 
Table 1: Home-ownership and Mortgage-debt among bankruptcy filers and CFM respondents (2003-2007)

\begin{tabular}{ccccccc}
\hline & \multicolumn{3}{c}{ Bankruptcies } & \multicolumn{3}{c}{ CFM Survey } \\
Year & Filers & Home Owner (\%) & Mortgage (\%) & Respondents & Home Owner (\%) & Mortgage (\%) \\
\hline 2003 & 91,203 & 0.265 & 0.242 & 12,342 & 0.822 & 0.388 \\
2004 & 90,791 & 0.206 & 0.191 & 12,987 & 0.829 & 0.381 \\
2005 & 90,563 & 0.193 & 0.180 & 11,023 & 0.824 & 0.362 \\
2006 & 84,363 & 0.186 & 0.179 & 12,000 & 0.765 & 0.314 \\
2007 & 84,603 & 0.178 & 0.173 & 12,016 & 0.762 & 0.299 \\
\hline
\end{tabular}

Table 2: Breakdown of liability types on bankruptcy filers' portfolios (2003-2007).

Other includes loans to individuals, lawyers, doctors, businesses. Since the CFM survey does not contain information on liabilities to the government, payday loans or other types of non-financial debt, these categories are excluded.

\begin{tabular}{lccccc}
\hline Category of Creditor & 2003 & 2004 & 2005 & 2006 & 2007 \\
\hline Panel A: Bankruptcy Filers & & & & & \\
Bank & 33.35 & 33.83 & 34.93 & 36.08 & 36.84 \\
Other financial & 16.30 & 15.69 & 14.77 & 13.69 & 13.27 \\
Non-bank Credit Cards & 19.45 & 19.81 & 19.70 & 19.69 & 20.00 \\
Government & 12.35 & 13.15 & 13.14 & 13.24 & 12.77 \\
Payday Lenders & 1.31 & 1.37 & 1.86 & 1.91 & 2.02 \\
Other & 17.23 & 16.15 & 15.60 & 15.39 & 15.04 \\
\hline Panel B: CFM Respondents & & & & & \\
Bank & 71.77 & 72.94 & 73.01 & 73.58 & 81.84 \\
Other financial & 2.82 & 2.88 & 2.80 & 3.01 & 2.73 \\
Non-bank Credit Cards & 25.41 & 24.17 & 23.39 & 23.41 & 15.42 \\
\hline
\end{tabular}

Table 3: Occupations - Bankruptcy Filer and CFM Respondent (1998-2007)

\begin{tabular}{lccc}
\hline Occupation & Bankruptcy Filer (\%) & CFM Female (\%) & CFM Male (\%) \\
\hline Sales and services & 18.45 & 8.65 & 7.99 \\
Unemployed & 16.34 & 2.68 & 7.15 \\
Laborer & 8.60 & 2.21 & 8.49 \\
Retired & 8.67 & 23.21 & 26.15 \\
Clerical & 7.76 & 11.26 & 2.17 \\
Manager & 5.59 & 9.99 & 12.56 \\
\hline
\end{tabular}


Table 4: Summary statistics for variables related to bankruptcy filings per capita, soft information capture, local market structure and credit supply.

\begin{tabular}{lccccc}
\hline & & & & & \\
Panel A: FSA-level variables & No of obs. & Mean & Std. Dev. & Min & Max \\
\hline Bankruptcy Filings per 1,000 & 4071 & 3.18 & 1.49 & 0.36 & 16.17 \\
& & & & & \\
$F S A+3 k m$ & & & & & \\
Soft Info, OSB & 3973 & 1.42 & 1.15 & 0.05 & 8 \\
Soft Info, CFM & 2668 & 1.30 & 1.02 & 0.05 & 11 \\
No of Branches & 3973 & 21.27 & 29.87 & 1.00 & 216 \\
HHI & 3973 & 0.25 & 0.19 & 0.09 & 1 \\
No of Banks & 3973 & 6.25 & 2.65 & 1.00 & 14 \\
& & & & & \\
FSA + 5km & & & & & \\
Soft Info, OSB & 4040 & 1.00 & 1.06 & 0.03 & 7.60 \\
Soft Info, CFM & 2707 & 0.87 & 0.87 & 0.03 & 6 \\
No of Branches & 4040 & 43.30 & 57.33 & 1.00 & 330 \\
HHI & 4040 & 0.21 & 0.15 & 0.09 & 1 \\
No of Banks & 4040 & 7.35 & 2.68 & 1.00 & 14 \\
& & & & & \\
FSA + 7km & & & & & \\
Soft Info, OSB & 4071 & 0.81 & 1.03 & 0.02 & 9 \\
Soft Info, CFM & 2714 & 0.66 & 0.79 & 0.02 & 8 \\
No of Branches & 4071 & 67.85 & 84.71 & 1.00 & 415 \\
HHI & 4071 & 0.20 & 0.14 & 0.10 & 1 \\
No of Banks & 4071 & 7.92 & 2.74 & 1.00 & 14 \\
\hline Panel B: "Large market-level" variables & No of obs. & Mean & Std. Dev. & Min & Max \\
\hline New Credit per Capita (Whole) & & & & & \\
New Credit per Capita (Sampling) & 4703 & 69.22 & 84.45 & 0.07 & 932.52 \\
New Credit per Capita (Rolling) & 3711 & 41.90 & 50.54 & 0.35 & 258.56 \\
& 4192 & 36.25 & 48.60 & 0.01 & 732.71 \\
\hline
\end{tabular}


Table 5: Baseline regressions on the impact of "soft information capture" (Soft Info ${ }_{i t}$ ) on bankruptcy rates. Dependent variable: log of bankruptcy filings per 1,000 residents in an FSA. The number of residents in an FSA is constructed by interpolating the 2001 and 2006 census, while the 2001 values are used for the census control variables. For specifications (i)-(iv), the sample is limited to (a) 2003-2007, (b) FSAs where at least $25 \%$ of the filers were e-filers in year $t$ and (c) there were at least 10 e-filers in year $t$. These specifications control for the selection bias that may arise out of these restrictions (Selection: Yes). CFM Cutoff is the minimum number of CFM survey respondents required for the inclusion of the FSA in the regression. Specifications that use census control variables, along with the financial literacy and "use of non-bank debt among bankruptcy filers" measures also include province fixed effects (not reported). All regressions include year fixed effects and a constant (not reported). Standard errors are clustered at the FSA level.

\begin{tabular}{|c|c|c|c|c|c|c|}
\hline Panel A: FSA + 3km & (i) & (ii) & (iii) & (iv) & $(\mathrm{v})$ & (vi) \\
\hline $\ln \left(\right.$ Soft $\left.\operatorname{Info}_{m t}\right)$ & $\begin{array}{c}0.1367^{* * *} \\
(0.030)\end{array}$ & $\begin{array}{c}0.0400^{* * *} \\
(0.014)\end{array}$ & $\begin{array}{c}0.0591^{* *} \\
(0.023)\end{array}$ & $\begin{array}{l}0.0179 \\
(0.014)\end{array}$ & $\begin{array}{c}0.0975 * * * \\
(0.028)\end{array}$ & $\begin{array}{l}0.0235 \\
(0.019)\end{array}$ \\
\hline $\mathrm{HHI}_{m t}$ & $\begin{array}{l}-0.023 \\
(0.187)\end{array}$ & $\begin{array}{l}-0.053 \\
(0.070)\end{array}$ & $\begin{array}{c}-0.048 \\
(0.256)\end{array}$ & $\begin{array}{l}-0.109 \\
(0.092)\end{array}$ & $\begin{array}{c}0.157 \\
(0.262)\end{array}$ & $\begin{array}{c}-0.268^{* *} \\
(0.134)\end{array}$ \\
\hline Data & OSB & OSB & CFM & CFM & CFM & CFM \\
\hline Sample & 03-07 & 03-07 & 03-07 & 03-07 & $99-07$ & $99-07$ \\
\hline Selection & Yes & Yes & Yes & Yes & No & No \\
\hline CFM Cutoff & & & 5 & 5 & 10 & 10 \\
\hline Market FE & Yes & No & Yes & No & Yes & No \\
\hline Census Controls & No & Yes & No & Yes & No & Yes \\
\hline Observations & 3,973 & 3,973 & 2,668 & 2,668 & 2,483 & 2,483 \\
\hline R-squared & 0.875 & 0.601 & 0.886 & 0.635 & 0.842 & 0.576 \\
\hline Panel B: FSA + 5km & (i) & (ii) & (iii) & (iv) & $(\mathrm{v})$ & (vi) \\
\hline $\ln \left(\right.$ Soft $\left.\operatorname{Info}_{m t}\right)$ & $\begin{array}{c}0.103^{* * *} \\
(0.031)\end{array}$ & $\begin{array}{c}0.058^{* * *} \\
(0.013)\end{array}$ & $\begin{array}{c}0.061^{* * *} \\
(0.023)\end{array}$ & $\begin{array}{c}0.047^{* * *} \\
(0.014)\end{array}$ & $\begin{array}{c}0.092^{* * *} \\
(0.028)\end{array}$ & $\begin{array}{c}0.042^{* *} \\
(0.018)\end{array}$ \\
\hline $\mathrm{HHI}_{m t}$ & $\begin{array}{l}-0.047 \\
(0.188)\end{array}$ & $\begin{array}{l}-0.108 \\
(0.071)\end{array}$ & $\begin{array}{l}-0.073 \\
(0.263)\end{array}$ & $\begin{array}{c}-0.166^{*} \\
(0.093)\end{array}$ & $\begin{array}{c}0.074 \\
(0.260)\end{array}$ & $\begin{array}{c}-0.324^{* *} \\
(0.138)\end{array}$ \\
\hline Data & OSB & OSB & CFM & CFM & CFM & CFM \\
\hline Sample & $03-07$ & $03-07$ & $03-07$ & $03-07$ & $99-07$ & $99-07$ \\
\hline Selection & Yes & Yes & Yes & Yes & No & No \\
\hline CFM Cutoff & & & 5 & 5 & 10 & 10 \\
\hline Market FE & Yes & No & Yes & No & Yes & No \\
\hline Census Controls & No & Yes & No & Yes & No & Yes \\
\hline Observations & 4,040 & 4,040 & 2,707 & 2,707 & 2,499 & 2,499 \\
\hline R-squared & 0.875 & 0.605 & 0.886 & 0.637 & 0.841 & 0.575 \\
\hline Panel C: FSA + 7km & (i) & (ii) & (iii) & (iv) & $(\mathrm{v})$ & (vi) \\
\hline $\ln \left(\right.$ Soft $\left.\operatorname{Info}_{m t}\right)$ & $\begin{array}{c}0.110^{* * *} \\
(0.029)\end{array}$ & $\begin{array}{c}0.082^{* * *} \\
(0.013)\end{array}$ & $\begin{array}{c}0.062^{* * *} \\
(0.022)\end{array}$ & $\begin{array}{c}0.080^{* * *} \\
(0.013)\end{array}$ & $\begin{array}{c}0.089^{* * *} \\
(0.027)\end{array}$ & $\begin{array}{c}0.0830^{* * *} \\
(0.017)\end{array}$ \\
\hline $\mathrm{HHI}_{m t}$ & $\begin{array}{l}-0.030 \\
(0.171)\end{array}$ & $\begin{array}{c}-0.159^{* *} \\
(0.076)\end{array}$ & $\begin{array}{l}-0.066 \\
(0.263)\end{array}$ & $\begin{array}{c}-0.273^{* * *} \\
(0.090)\end{array}$ & $\begin{array}{c}0.056 \\
(0.258)\end{array}$ & $\begin{array}{c}-0.461^{* * *} \\
(0.147)\end{array}$ \\
\hline Data & OSB & OSB & CFM & CFM & CFM & CFM \\
\hline Sample & $03-07$ & $03-07$ & 03-07 & $03-07$ & $99-07$ & $99-07$ \\
\hline Selection & Yes & Yes & Yes & Yes & No & No \\
\hline CFM Cutoff & & & 5 & 5 & 10 & 10 \\
\hline Market FE & Yes & No & Yes & No & Yes & No \\
\hline Census Controls & No & Yes & No & Yes & No & Yes \\
\hline Observations & 4,071 & 4,071 & 2,714 & 2,714 & 2,499 & 2,499 \\
\hline R-squared & 0.874 & 0.602 & 0.886 & 0.645 & 0.841 & 0.583 \\
\hline
\end{tabular}


Table 6: Impact of the TD-Canada Trust (Panel A) merger and the Laurentian Bank (LB) - TD branch sale (Panel B) on bankruptcies per capita. Dependent variable: log of bankruptcy filings per 1,000 residents in an FSA. The year of the merger (2000 for TD-Canada Trust and 2003 for LB-TD) is excluded from the analysis. Specification (i) uses two years before (Before Window) and two years after (After Window) the merger. Specification (ii) uses two years before and three years after. For the TD-LB acquisition, FSAs in QC and Ottawa, ON were dropped from the sample, since those markets were not involved in the sale. The row "Population" refers to the source of the population figures that were used in the calculation of the dependent variable. Heteroscedasticity-robust standard errors are given in parentheses.

\begin{tabular}{|c|c|c|c|c|c|c|}
\hline \multirow[t]{2}{*}{ Panel A: TD-CT } & \multicolumn{2}{|c|}{$\mathrm{FSA}+3 \mathrm{~km}$} & \multicolumn{2}{|c|}{$\mathrm{FSA}+5 \mathrm{~km}$} & \multicolumn{2}{|c|}{$\mathrm{FSA}+7 \mathrm{~km}$} \\
\hline & (i) & (ii) & (i) & (ii) & (i) & (ii) \\
\hline \multirow[t]{2}{*}{ Treat*Post } & $0.030^{*}$ & $0.050^{* * *}$ & $0.033^{*}$ & $0.053^{* * *}$ & $0.034^{*}$ & $0.055^{* * *}$ \\
\hline & $(0.016)$ & $(0.015)$ & $(0.018)$ & $(0.017)$ & $(0.019)$ & $(0.018)$ \\
\hline \multirow[t]{2}{*}{ Post } & 0.010 & $0.054^{* * *}$ & 0.005 & $0.046^{* * *}$ & 0.002 & $0.042^{* *}$ \\
\hline & $(0.016)$ & $(0.015)$ & $(0.018)$ & $(0.017)$ & $(0.019)$ & $(0.018)$ \\
\hline \multirow[t]{2}{*}{ Constant } & $0.915^{* * *}$ & $0.916^{* * *}$ & $0.913^{* * *}$ & $0.915^{* * *}$ & $0.913^{* * *}$ & $0.915^{* * *}$ \\
\hline & $(0.008)$ & $(0.008)$ & $(0.008)$ & $(0.008)$ & $(0.008)$ & $(0.008)$ \\
\hline Before Window & $98-99$ & $98-99$ & $98-99$ & $98-99$ & $98-99$ & $98-99$ \\
\hline After Window & $01-02$ & 01-03 & 01-02 & 01-03 & 01-02 & 01-03 \\
\hline FSA FE & Yes & Yes & Yes & Yes & Yes & Yes \\
\hline Year FE & Yes & Yes & Yes & Yes & Yes & Yes \\
\hline Population & Imputed & Imputed & Imputed & Imputed & Imputed & Imputed \\
\hline Observations & 4,404 & 5,521 & 4,392 & 5,505 & 4,388 & 5,500 \\
\hline R-squared & 0.812 & 0.795 & 0.810 & 0.794 & 0.810 & 0.794 \\
\hline \multirow[t]{2}{*}{ Panel B: LB-TD } & \multicolumn{2}{|c|}{$\mathrm{FSA}+3 \mathrm{~km}$} & \multicolumn{2}{|c|}{$\mathrm{FSA}+5 \mathrm{~km}$} & \multicolumn{2}{|c|}{$\mathrm{FSA}+7 \mathrm{~km}$} \\
\hline & (i) & (ii) & (i) & (ii) & (i) & (ii) \\
\hline \multirow[t]{2}{*}{ Treat*Post } & $0.038^{*}$ & $0.064^{* * *}$ & $0.049 * *$ & $0.073^{* * *}$ & $0.055^{* * *}$ & $0.076^{* * *}$ \\
\hline & $(0.021)$ & $(0.020)$ & $(0.019)$ & $(0.018)$ & $(0.019)$ & $(0.018)$ \\
\hline \multirow[t]{2}{*}{ Post } & 0.010 & $-0.109^{* * *}$ & -0.010 & $-0.142^{* * *}$ & -0.020 & $-0.153^{* * *}$ \\
\hline & $(0.016)$ & $(0.017)$ & $(0.017)$ & $(0.017)$ & $(0.017)$ & $(0.018)$ \\
\hline \multirow[t]{2}{*}{ Constant } & $0.930^{* * *}$ & $0.928^{* * *}$ & $0.926^{* * *}$ & $0.924^{* * *}$ & $0.917^{* * *}$ & $0.915^{* * *}$ \\
\hline & $(0.009)$ & $(0.010)$ & $(0.009)$ & $(0.010)$ & $(0.009)$ & $(0.010)$ \\
\hline Before Window & 01-02 & 01-02 & 01-02 & 01-02 & 01-02 & 01-02 \\
\hline After Window & $04-05$ & 04-06 & $04-05$ & 04-06 & 04-05 & 04-06 \\
\hline FSA FE & Yes & Yes & Yes & Yes & Yes & Yes \\
\hline Year FE & Yes & Yes & Yes & Yes & Yes & Yes \\
\hline Population & Imputed & Imputed & Imputed & Imputed & Imputed & Imputed \\
\hline Observations & 2,255 & 2,813 & 2,572 & 3,209 & 2,713 & 3,384 \\
\hline R-squared & 0.852 & 0.827 & 0.840 & 0.820 & 0.836 & 0.817 \\
\hline
\end{tabular}


Table 7: Impact of the TD-Canada Trust (Panel A) merger and the Laurentian Bank (LB) - TD branch sale (Panel B) on branches per capita. Dependent variable: log of the number of bank branches per 1,000 residents in an FSA. The year of the merger (2000 for TD-Canada Trust and 2003 for LB-TD) is excluded from the analysis. Specification (i) uses two years before (Before Window) and two years after (After Window) the merger. Specification (ii) uses two years before and three years after. For the TD-LB acquisition, FSAs in QC and Ottawa, ON were dropped from the sample, since those markets were not involved in the sale. The row "Population" refers to the source of the population figures that were used in the calculation of the dependent variable. Heteroscedasticity-robust standard errors are given in parentheses.

\begin{tabular}{|c|c|c|c|c|c|c|}
\hline \multirow[t]{2}{*}{ Panel A: TD-CT } & \multicolumn{2}{|c|}{$\mathrm{FSA}+3 \mathrm{~km}$} & \multicolumn{2}{|c|}{$\mathrm{FSA}+5 \mathrm{~km}$} & \multicolumn{2}{|c|}{$\mathrm{FSA}+7 \mathrm{~km}$} \\
\hline & (i) & (ii) & (i) & (ii) & (i) & (ii) \\
\hline Treat*Post & $\begin{array}{c}-0.015^{* * *} \\
(0.004)\end{array}$ & $\begin{array}{c}-0.025^{* * *} \\
(0.003)\end{array}$ & $\begin{array}{c}-0.009^{* *} \\
(0.004)\end{array}$ & $\begin{array}{c}-0.017^{* * *} \\
(0.004)\end{array}$ & $\begin{array}{l}-0.002 \\
(0.004)\end{array}$ & $\begin{array}{c}-0.008^{*} \\
(0.004)\end{array}$ \\
\hline Post & $\begin{array}{c}-0.040^{* * *} \\
(0.004)\end{array}$ & $\begin{array}{c}-0.043^{\text {*** }} \\
(0.004)\end{array}$ & $\begin{array}{c}-0.059^{* * *} \\
(0.004)\end{array}$ & $\begin{array}{c}-0.067^{* * *} \\
(0.004)\end{array}$ & $\begin{array}{c}-0.073^{* * *} \\
(0.005)\end{array}$ & $\begin{array}{c}-0.083^{\text {*** }} \\
(0.005)\end{array}$ \\
\hline Constant & $\begin{array}{c}0.669^{* * *} \\
(0.001)\end{array}$ & $\begin{array}{c}0.668^{* * *} \\
(0.002)\end{array}$ & $\begin{array}{c}1.030 * * * \\
(0.001)\end{array}$ & $\begin{array}{c}1.029 * * * \\
(0.002)\end{array}$ & $\begin{array}{c}1.309^{* * * *} \\
(0.001)\end{array}$ & $\begin{array}{c}1.308^{* * * *} \\
(0.002)\end{array}$ \\
\hline Before Window & $98-99$ & $98-99$ & $98-99$ & $98-99$ & $98-99$ & $98-99$ \\
\hline After Window & 01-02 & 01-03 & 01-02 & 01-03 & 01-02 & 01-03 \\
\hline FSA FE & Yes & Yes & Yes & Yes & Yes & Yes \\
\hline Year FE & Yes & Yes & Yes & Yes & Yes & Yes \\
\hline Population & Imputed & Imputed & Imputed & Imputed & Imputed & Imputed \\
\hline Observations & 4,328 & 5,426 & 4,316 & 5,410 & 4,312 & 5,405 \\
\hline R-squared & 0.993 & 0.990 & 0.996 & 0.993 & 0.997 & 0.995 \\
\hline \multirow[t]{2}{*}{ Panel B: LB-TD } & \multicolumn{2}{|c|}{$\mathrm{FSA}+3 \mathrm{~km}$} & \multicolumn{2}{|c|}{$\mathrm{FSA}+5 \mathrm{~km}$} & \multicolumn{2}{|c|}{$\mathrm{FSA}+7 \mathrm{~km}$} \\
\hline & (i) & (ii) & (i) & (ii) & (i) & (ii) \\
\hline Treat*Post & $\begin{array}{c}-0.036^{* * *} \\
(0.005)\end{array}$ & $\begin{array}{c}-0.038^{* * *} \\
(0.005)\end{array}$ & $\begin{array}{c}-0.037^{* * *} \\
(0.004)\end{array}$ & $\begin{array}{c}-0.040^{* * *} \\
(0.004)\end{array}$ & $\begin{array}{c}-0.035^{* * *} \\
(0.004)\end{array}$ & $\begin{array}{c}-0.038^{* * *} \\
(0.004)\end{array}$ \\
\hline Post & -0.003 & $-0.011^{* * *}$ & 0.004 & $-0.006^{* *}$ & $0.008^{* *}$ & -0.004 \\
\hline & $(0.003)$ & $(0.003)$ & $(0.003)$ & $(0.003)$ & $(0.003)$ & $(0.003)$ \\
\hline Constant & $0.629 * * *$ & $0.628^{* * *}$ & $0.957^{* * *}$ & $0.956^{* * *}$ & $1.217^{* * *}$ & $1.217^{* * *}$ \\
\hline & $(0.002)$ & $(0.002)$ & $(0.002)$ & $(0.002)$ & $(0.002)$ & $(0.002)$ \\
\hline Before Window & 01-02 & 01-02 & 01-02 & 01-02 & 01-02 & 01-02 \\
\hline After Window & 04-05 & 04-06 & 04-05 & 04-06 & 04-05 & 04-06 \\
\hline FSA FE & Yes & Yes & Yes & Yes & Yes & Yes \\
\hline Year FE & Yes & Yes & Yes & Yes & Yes & Yes \\
\hline Population & Imputed & Imputed & Imputed & Imputed & Imputed & Imputed \\
\hline Observations & 2,255 & 2,813 & 2,572 & 3,209 & 2,713 & 3,384 \\
\hline R-squared & 0.992 & 0.992 & 0.995 & 0.995 & 0.997 & 0.997 \\
\hline
\end{tabular}


Table 8: Impact of the TD-Canada Trust (Panel A) merger and the Laurentian Bank (LB) - TD branch sale (Panel B) on quantity supplied of credit. Dependent variable: $\log$ of loans per capita issued in large market $j$ at year $t$. Rural FSAs and towns covered by a single FSA are considered an individual market. Towns that are covered by up to 13 FSAs are also individual markets. Large urban areas covered by 14 FSAs or more are divided into smaller markets each consisting of 7 to 13 FSAs. The year of the merger (2000 for TD-Canada Trust and 2003 for LB-TD) is excluded from the analysis. The sample period consists of uses two years before and two years after the merger (1999-2000 and 2001-2003 for TD-Canada Trust, 2001-2002 and 2004-2005 for LB-TD). For TD-LB, markets located in $\mathrm{QC}$ and Ottawa, ON were dropped from the sample, since those markets were not involved in the sale. The sample is limited to markets for which there is credit supply data available for at least three of the four years in the sample. The row "Population" refers to the source of the population figures that were used in the calculation of the dependent variable. Heteroscedasticity-robust standard errors are given in parentheses.

\begin{tabular}{|c|c|c|c|}
\hline \multirow[t]{2}{*}{ Panel A: TD-CT } & \multirow[b]{2}{*}{ Whole } & \multirow[b]{2}{*}{ Sampling } & \multirow[b]{2}{*}{ Rolling } \\
\hline & & & \\
\hline Treat*Post & $\begin{array}{c}0.009 \\
(0.088)\end{array}$ & $\begin{array}{l}-0.127 \\
(0.128)\end{array}$ & $\begin{array}{c}0.060 \\
(0.105)\end{array}$ \\
\hline Post & $\begin{array}{c}-0.302^{* * *} \\
(0.076)\end{array}$ & $\begin{array}{c}-0.206^{*} \\
(0.107)\end{array}$ & $\begin{array}{c}0.245^{* * *} \\
(0.086)\end{array}$ \\
\hline Constant & $\begin{array}{c}3.876^{* * *} \\
(0.044)\end{array}$ & $\begin{array}{c}3.089^{* * *} \\
(0.064)\end{array}$ & $\begin{array}{c}2.617^{* * *} \\
(0.054)\end{array}$ \\
\hline FSA FE & Yes & Yes & Yes \\
\hline Year FE & Yes & Yes & Yes \\
\hline Population & 2001 & 2001 & 2001 \\
\hline Observations & 1,995 & 1,472 & 1,770 \\
\hline R-squared & 0.579 & 0.457 & 0.506 \\
\hline \multirow[t]{2}{*}{ Panel B: TD-LB } & & & \\
\hline & Whole & Sampling & Rolling \\
\hline Treat*Post & $\begin{array}{l}-0.223 \\
(0.157)\end{array}$ & $\begin{array}{l}-0.075 \\
(0.187)\end{array}$ & $\begin{array}{l}-0.210 \\
(0.175)\end{array}$ \\
\hline Post & $\begin{array}{c}-0.363^{* * *} \\
(0.093)\end{array}$ & $\begin{array}{c}0.285^{* *} \\
(0.113)\end{array}$ & $\begin{array}{l}-0.110 \\
(0.099)\end{array}$ \\
\hline Constant & $\begin{array}{c}3.694^{* * *} \\
(0.058)\end{array}$ & $\begin{array}{c}2.908^{* * * *} \\
(0.074)\end{array}$ & $\begin{array}{c}2.928^{* * *} \\
(0.059)\end{array}$ \\
\hline Market FE & Yes & Yes & Yes \\
\hline Year FE & Yes & Yes & Yes \\
\hline Population & 2001 & 2001 & 2001 \\
\hline Observations & 1,345 & 1,093 & 1,172 \\
\hline R-squared & 0.532 & 0.483 & 0.516 \\
\hline
\end{tabular}


Table 9: Impact of the TD-Canada Trust merger on the market share of TD-Canada Trust. Dependent variable: loan count-based market share of TD-Canada Trust market $i$ at year $t$, calculated using CFM data and log transformed $(y=\ln (x /(1-x)))$. Rural FSAs and towns covered by a single FSA are considered an individual market. Towns that are covered by up to 13 FSAs are also individual markets. Large urban areas covered by 14 FSAs or more are divided into smaller markets each consisting of 7 to 13 FSAs. The year of the merger (2000) is excluded from the analysis. The sample is limited to one year before and two years after the merger (1999 and 2001-2002). Heteroscedasticity-robust standard errors are given in parentheses.

\begin{tabular}{lccc}
\hline & All Liabilities & Credit Cards & Mortgages \\
Treat*Post & $-0.048^{* * *}$ & $-0.110^{* * *}$ & $-0.402^{* * *}$ \\
& $(0.005)$ & $(0.006)$ & $(0.022)$ \\
Post & $-0.098^{* * *}$ & $-0.208^{* * *}$ & $0.196^{* * *}$ \\
& $(0.004)$ & $(0.005)$ & $(0.021)$ \\
Constant & $-2.260^{* * *}$ & $-2.410^{* * *}$ & $-1.473^{* * *}$ \\
& $(0.002)$ & $(0.002)$ & $(0.007)$ \\
& & & \\
Market FE & Yes & Yes & Yes \\
Year FE & Yes & Yes & Yes \\
& & & \\
Obs. & 1,745 & 1,598 & 862 \\
R-squared & 0.780 & 0.726 & 0.735 \\
\hline
\end{tabular}

Table 10: Regressions on the impact of "soft information capture" (Soft Info $_{\text {lit }}$ ) on bankruptcy at the bank-market level. Dependent variable, the percentage of lender l's customers in market $i$ who declared bankruptcy in year $t$, $\log$ transformed $(y=\ln (x /(1-x)))$. The sample is limited to (a) 2003-2007, (b) FSAs where at least $25 \%$ of the filers were e-filers in year $t$ and (c) there were at least 10 e-filers in year $t$. All three of specifications control for the selection bias that may arise out of these restrictions. All regressions include year fixed effects. The standard errors in parentheses are clustered at the FSA level.

\begin{tabular}{lccc}
\hline & FSA $+3 \mathrm{~km}$ & FSA $+5 \mathrm{~km}$ & $\mathrm{FSA}+7 \mathrm{~km}$ \\
$\ln \left({\left.\text { Soft } \text { Info }_{l i t}\right)}\right)$ & $0.115^{* * *}$ & $0.085^{* * *}$ & $0.081^{* * *}$ \\
& $(0.028)$ & $(0.028)$ & $(0.028)$ \\
$\mathrm{HHI}_{m t}$ & -0.332 & 0.430 & 0.347 \\
& $(0.544)$ & $(0.657)$ & $(0.730)$ \\
Constant & $-6.030^{* * *}$ & $-6.213^{* * *}$ & $-6.171^{* * *}$ \\
& $(0.218)$ & $(0.203)$ & $(0.212)$ \\
& & & \\
Sample & $03-07$ & $03-07$ & $03-07$ \\
Selection & Yes & Yes & Yes \\
Bank FE & Yes & Yes & Yes \\
Market FE & Yes & Yes & Yes \\
Year FE & Yes & Yes & Yes \\
& & & \\
Obs. & 10,564 & 11,483 & 11,797 \\
R-squared & 0.436 & 0.427 & 0.424 \\
\hline
\end{tabular}


Table 11: Regressions that define "soft information capture" (Soft Info $_{i t}$ ) as loans per branch (in logs). Dependent variable: log of bankruptcy filings per 1,000 residents in an FSA. For specifications (i) and (ii), the sample is limited to (a) 2003-2007, (b) FSAs where at least $25 \%$ of the filers were e-filers in year $t$ and (c) there were at least 10 e-filers in year $t$. Both specifications control for the selection bias that may arise out of these restrictions (Selection: Yes). CFM Cutoff specifies the minimum number of CFM survey respondents in an FSA required for the inclusion of the FSA in the regression. All regressions include year fixed effects and a constant (not reported). Standard errors are clustered at the FSA level.

\begin{tabular}{|c|c|c|c|}
\hline Panel A: FSA + $3 \mathrm{~km}$ & (i) & (ii) & (iii) \\
\hline $\ln \left(\right.$ Soft $\left.\operatorname{Info}_{i t}\right)$ & $\begin{array}{c}0.256^{* * *} \\
(0.026)\end{array}$ & $\begin{array}{c}0.221^{* *} \\
(0.101)\end{array}$ & $\begin{array}{c}0.034 \\
(0.136)\end{array}$ \\
\hline $\mathrm{HHI}_{m t}$ & $\begin{array}{l}-0.118 \\
(0.121)\end{array}$ & $\begin{array}{c}-0.261^{*} \\
(0.157)\end{array}$ & $\begin{array}{c}-0.118 \\
(0.133)\end{array}$ \\
\hline Data & OSB & CFM & CFM \\
\hline Sample & $03-07$ & $03-07$ & $99-07$ \\
\hline Selection & Yes & Yes & No \\
\hline CFM Cutoff & & 5 & 10 \\
\hline Market FE & Yes & Yes & Yes \\
\hline Observations & 3,746 & 2,602 & 2,413 \\
\hline R-squared & 0.893 & 0.888 & 0.841 \\
\hline Panel B: FSA + 5km & (i) & (ii) & (iii) \\
\hline $\ln \left(\right.$ Soft $\left.\operatorname{Info}_{i t}\right)$ & $\begin{array}{c}0.179^{* * *} \\
(0.019)\end{array}$ & $\begin{array}{c}0.188^{* *} \\
(0.093)\end{array}$ & $\begin{array}{c}0.048 \\
(0.129)\end{array}$ \\
\hline $\mathrm{HHI}_{m t}$ & $\begin{array}{l}-0.179 \\
(0.167)\end{array}$ & $\begin{array}{l}-0.291 \\
(0.250)\end{array}$ & $\begin{array}{c}-0.317 \\
(0.273)\end{array}$ \\
\hline Data & OSB & CFM & CFM \\
\hline Sample & $03-07$ & $03-07$ & $99-07$ \\
\hline Selection & Yes & Yes & No \\
\hline CFM Cutoff & & 5 & 10 \\
\hline Market FE & Yes & Yes & Yes \\
\hline Observations & 3,528 & 2,639 & 2,428 \\
\hline R-squared & 0.893 & 0.888 & 0.841 \\
\hline Panel C: FSA + 7km & (i) & (ii) & (iii) \\
\hline $\ln \left(\right.$ Soft $\left.\operatorname{Info}_{i t}\right)$ & $\begin{array}{c}0.180 * * * \\
(0.018)\end{array}$ & $\begin{array}{c}0.185^{* *} \\
(0.088)\end{array}$ & $\begin{array}{c}0.012 \\
(0.120)\end{array}$ \\
\hline $\mathrm{HHI}_{m t}$ & $\begin{array}{l}-0.086 \\
(0.168)\end{array}$ & $\begin{array}{l}-0.179 \\
(0.259)\end{array}$ & $\begin{array}{c}0.065 \\
(0.262)\end{array}$ \\
\hline Data & OSB & CFM & CFM \\
\hline Sample & $03-07$ & $03-07$ & $99-07$ \\
\hline Selection & Yes & Yes & No \\
\hline CFM Cutoff & & 5 & 10 \\
\hline Market FE & Yes & Yes & Yes \\
\hline Observations & 3,253 & 2,645 & 2,428 \\
\hline R-squared & 0.894 & 0.887 & 0.841 \\
\hline
\end{tabular}

